\title{
Recent advances in biochar application for water and wastewater treatment: A review
}

\author{
Xiaoqing Wang ${ }^{1}$, Zizhang Guo ${ }^{1}$, Zhen Hu ${ }^{\text {Corresp., } 1}{ }^{1}$, Jian Zhang ${ }^{\text {Corresp. } 1}$ \\ ${ }^{1}$ Shandong Key Laboratory of Water Pollution Control and Resource Reuse, School of Environmental Science \& Engineering, Shandong University, \\ Qingdao, P.R.China \\ Corresponding Authors: Zhen Hu, Jian Zhang \\ Email address: huzhen885@sdu.edu.cn, zhangjian00@sdu.edu.cn
}

In the past decade, researchers have carried out a massive amount of research on the application of biochar for contaminants removal from aqueous solutions. As an emerging sorbent with great potential, biochar has shown significant advantages such as the broad sources of feedstocks, easy preparation process, and favorable surface and structural properties. This review provides an overview of recent advances in biochar application in water and wastewater treatment, including a brief discussion of the involved sorption mechanisms of contaminants removal, as well as the biochar modification methods. Furthermore, environmental concerns of biochar that need to be paid attention to and future research directions are put forward to promote the further application of biochar in practical water and wastewater treatment. 
1

2 Recent advances in biochar application for water and 3 wastewater treatment: A review

4

5

6

7

8
Xiaoqing Wang ${ }^{1}$, Zizhang Guo ${ }^{1}$, Zhen $\mathrm{Hu}^{1}$, Jian Zhang ${ }^{1,2}$

${ }^{1}$ Shandong Key Laboratory of Water Pollution Control and Resource Reuse, School of

Environmental Science \& Engineering, Shandong University, Qingdao 266237, P.R.China

${ }^{2}$ State Key Laboratory of Microbial Technology, Shandong University, Jinan 250100, P.R.China

Corresponding Author:

Jian Zhang ${ }^{1,2}$

27 Shanda Nanlu, Jinan, Shandong, 250100, P.R.China

Email address: zhangjian00@sdu.edu.cn 


\section{Abstract}

41 In the past decade, researchers have carried out a massive amount of research on the application

42

43

44

45

46

47

48

49

50

51

52

53

54

55

56

57

58

59

60

61

62

63

64

65

66

67

68

69

70

71

72

73

74

75

76

77

78

79

of biochar for contaminants removal from aqueous solutions. As an emerging sorbent with great potential, biochar has shown significant advantages such as the broad sources of feedstocks, easy preparation process, and favorable surface and structural properties. This review provides an overview of recent advances in biochar application in water and wastewater treatment, including a brief discussion of the involved sorption mechanisms of contaminants removal, as well as the biochar modification methods. Furthermore, environmental concerns of biochar that need to be paid attention to and future research directions are put forward to promote the further application of biochar in practical water and wastewater treatment.

\section{Introduction}

Biochar with rich carbon content is a thermal decomposition product derived from biomass under a condition that lacks oxygen (Sohi, 2012). These innovations about converting organic matters into valuable materials such as biochar and the subsequent applications have drawn the attention of relevant fields. Initial studies have focused on the ability of biochars as soil amendments to sorb inorganic nutrients and improve the soil quality or promote other environmental services (Sanroman et al., 2017a). Numerous researches have shown the interests of biochar in improving soil properties and increasing crop yield (Windeatt et al., 2014; Agegnehu et al., 2017; Awad et al., 2017; ÖZ, 2018; Yu et al., 2019), which ultimately contributes to soil carbon sequestration and reduction of greenhouse gases (Windeatt et al., 2014). In recent years, progress in the production of various biochars has improved their performance and expanded their application in multidisciplinary fields. Researches on biochar are being carried out in more and more countries, with broad and diverse purposes depending on the feedstocks, production and modification methods, and the local economy and environment (Tan et al., 2015).

Water and wastewater treatment is one of the emerging subsets of biochar application. Due to the properties of large surface area and pore volume, rich organic carbon content and mineral components, abundant and diverse functional groups, biochar displays prominent sorption ability for both inorganic and organic contaminants in aqueous solutions (Ahmad et al., 2014). Traditional techniques for contaminants removal from the aqueous phase, for example, ion exchange, membrane separation, chemical precipitation, and sorption using activated carbon, have disadvantages such as high cost and inevitable generation of a large number of chemical residues with no economic value (Oliveira et al., 2017). In contrast, biochar can be produced from green wastes, mainly agricultural biomass and solid wastes such as woodchips, straws, shells, bagasse, and manure (Ahmad et al., 2014; Nanda et al., 2016; Thornley et al., 2009). The resources of feedstocks are among the wealthiest renewable resources in the ecosystem (Yao et al., 2012; Xu et al., 2013), providing more options to produce such renewable sorbents, which benefits the low-income communities to some extent. Moreira et al. (2017) compared the global 
80

81

82

83

84

85

86

87

88

89

90

91

92

93

94

95

96

97

98

99

100

101

102

103

104

105

106

107

108

109

110

111

112

113

114

115

116

117

118

119

environmental impacts between the production process of biochar and activated carbon. The main findings encouraged biochar to be an environmentally friendly alternative to activated carbon, mainly reflected by net mitigation of carbon emissions in the biochar production process.

Biochar is a by-product of thermochemical transformation such as pyrolysis, hydrothermal carbonization, gasification, and torrefaction (Meyer et al., 2011). Reports have shown that the physicochemical properties of biochar such as surface area, porosity, acid-base behavior, surface functional groups, and element composition depend on pyrolysis temperatures and feedstock types (Ahmad et al., 2014; Uchimiya et al., 2013; Nachenius et al., 2013; Manariotis et al., 2015), making vital implications on its efficiency and suitability in removal of target contaminants (Oliveira et al., 2017), including a series of organic contaminants (e.g., dyes, phenols, polycyclic aromatic hydrocarbons (PAHs), pesticides, antibiotics) and inorganic contaminants (e.g., heavy metals, nitrate $\left(\mathrm{NO}_{3}{ }^{-}\right)$, ammonium ion $\left(\mathrm{NH}_{4}{ }^{+}\right)$, phosphate $\left(\mathrm{PO}_{4}{ }^{3-}\right)$, fluoride $\left(\mathrm{F}^{-}\right)$) from wastewater (detailed discussion is given in the section "Biochar application in water and wastewater treatment").

With increased application of biochar being carried out in the water and wastewater treatment, this paper reviews recent advances in the biochar application, including a brief discussion of the involved mechanisms in the removal of specific organic and inorganic contaminants. Moreover, this review briefly covers the modification methods of biochar based on different emphases and explains how the modification alters the properties of biochar, as well as the removal efficiency. Furthermore, remained environmental concerns and future research directions are highlighted, with possible solutions put forward.

\section{Survey methodology}

The literature reviewed in this paper was obtained on databases of ScienceDirect, Web of Science, Google Scholar, and the Chinese journal database CNKI. The keywords used to search for literature on the databases are as follows: biochar, cellulose, lignin, pyrolysis, and carbonization associated with the feedstocks and biochar production methods; industrial, agricultural, pharmaceutical, heavy metals, dyes, pesticides, antibiotics, and persistent contaminants reflecting biochar application; electrostatic interaction, precipitation, complexation, hydrophobic effect, and chemical bonds referred to sorption mechanisms; porosity, surface area, functional groups, magnetization, and biochar-based composites related to modification methods. Besides, literature research was specially conducted within the papers on "Special Issue on Biochar: Production, Characterization and Applications - Beyond Soil Applications" published on "Bioresource Technology," and papers published on "Journal of Chemical Technology and Biotechnology," which were presented in the 2017 European Geosciences Union session "Novel Sorbents for Environmental Remediation" (Sanroman et al., 2017b; Manariotis et al., 2017).

\section{Sorption mechanisms}


120 The sorption ability of biochar for contaminant removal has been well documented. However,

121

122

123

124

125

126

127

128

129

130

131

132

133

134

135

136

137

138

139

140

141

142

143

144

145

146

147

148

149

150

151

152

153

154

155

156

157

158

159

there are lacking studies on corresponding sorption mechanisms for target contaminants, which have fundamental meanings for improving the removal efficiency. Sorption mechanisms vary according to the properties of both contaminants and biochar. Here, the dominant mechanisms in the removal of heavy metals and organic contaminants are illustrated in Figure 1.

\section{Heavy metals}

Heavy metals in the water environment mostly come from anthropogenic activities such as smelting, mining, and electronic manufacturing effluents ( $\mathrm{Li}$ et al., 2017). Biochar has been suggested to be used for heavy metals removal from contaminated water. Removal mechanisms vary depending on the valence state of the target metal at different solution $\mathrm{pH}$ (Li et al., 2017). Four mechanisms dominating heavy metals removal from water by biochar are proposed as follows (Qian et al., 2015; Tan et al., 2015; Li et al., 2017): (i) electrostatic attraction between heavy metals and biochar surface; (ii) ion exchange between heavy metals and alkali or alkaline earth metals or protons on biochar surface; (iii) complexation with $\pi$ electron-rich domain or surface functional groups; (iv) co-precipitation to form insoluble compounds. Here, specific examples are used to explain each mechanism.

Solution $\mathrm{pH}$ could strongly influence the surface charge of biochar. $\mathrm{pH}_{\mathrm{PZC}}$ is the solution $\mathrm{pH}$ at which the net charge of the biochar surface is zero. Biochar is positively charged at solution $\mathrm{pH}$ $<\mathrm{pH}_{\mathrm{PZC}}$ and binds metal anions such as $\mathrm{HAsO}_{4}{ }^{2-}$ and $\mathrm{HCrO}_{4}^{-}$. On the contrary, biochar is negatively charged at solution $\mathrm{pH}>\mathrm{pH}_{\mathrm{PZC}}$ and binds metal cations such as $\mathrm{Hg}^{2+}, \mathrm{Pb}^{2+}$, and $\mathrm{Cd}^{2+}$ (Li et al., 2017). These processes are the electrostatic attraction. For instance, Wang et al. (2015) applied pinewood biochar pyrolyzed at $600^{\circ} \mathrm{C}\left(\mathrm{pH}_{\mathrm{PZC}}>7\right)$ to sorb $\mathrm{As}(\mathrm{V})$ from water at $\mathrm{pH} 7$, with a maximum sorption capacity of $0.3 \mathrm{mg} \cdot \mathrm{g}^{-1}$. $\mathrm{As}(\mathrm{V})$ mainly exists in the form of $\mathrm{HAsO}_{4}{ }^{2-}$ at $\mathrm{pH}$ 7. The biochar surface is positively charged since the solution $\mathrm{pH}<\mathrm{pH}_{\mathrm{PZC}}$. In that case, $\mathrm{HAsO}_{4}{ }^{2-}$ interacts with the protonated functional groups on biochar surface by electrostatic attraction.

Biochar pyrolyzed from biomass has plenty of exchangeable cations on the surface, such as some alkali or alkaline earth metals $(\mathrm{Na}, \mathrm{K}, \mathrm{Mg}, \mathrm{Ca})$ that can be replaced by heavy metal ions during the sorption. Lu et al. (2012) studied mechanisms for $\mathrm{Pb}$ sorption by sludge-derived biochar. They found a certain amount of $\mathrm{Na}^{+}, \mathrm{K}^{+}, \mathrm{Mg}^{2+}$, and $\mathrm{Ca}^{2+}$ released from the biochar, probably as a result of metal exchanges with $\mathrm{Pb}^{2+}$. Zhang et al. (2015) studied mechanisms for Cd sorption and showed that there was almost an equal amount of sorbed $\mathrm{Cd}$ and total released cations $(\mathrm{Na}, \mathrm{K}$, $\mathrm{Mg}, \mathrm{Ca}$ ) from the biochar, indicating the cation exchange as a leading role in Cd sorption.

Xu et al. (2016) compared different complexation mechanisms of Hg sorption on bagasse and hickory chips biochar. X-ray photoelectric spectroscopy (XPS) showed that the formation of ($\mathrm{COO})_{2} \mathrm{Hg}$ and $(-\mathrm{O})_{2} \mathrm{Hg}$ attributed mostly to $\mathrm{Hg}$ sorption on bagasse biochar. The sorption 
160

161

162

163

164

165

166

167

168

169

170

171

172

173

174

175

176

177

178

179

180

181

182

183

184

185

186

187

188

189

190

191

192

193

194

195

196

197

198

199

capacity decreased by $18 \%$ and $38 \%$ when using methanol to block - $\mathrm{COOH}$ and $-\mathrm{OH}$ functional groups. Nevertheless, the blocking did not affect $\mathrm{Hg}$ sorption on hickory chips biochar since the formation of $\mathrm{Hg}-\pi$ bindings between $\mathrm{Hg}$ and $\pi$ electrons of $\mathrm{C}=\mathrm{O}$ and $\mathrm{C}=\mathrm{C}$ dominated the sorption. Pan et al. (2013) investigated $\mathrm{Cr}$ (III) sorption on several crop straws biochars. The order of their sorption capacity was in accordance with the abundance of oxygen-containing functional groups, suggesting the importance of $\mathrm{Cr}$ (III) complexation with functional groups.

Mineral components in biochar are also crucial in the removal process, which acts as other sorption sites and makes contributions to heavy metals sorption by precipitation (Xu et al., 2013). For example, precipitation was implied to be the dominant mechanism for $\mathrm{Cd}$ removal on dairy manure biochar owing to its relatively high soluble carbonate and phosphate content $\mathrm{Xu}$ et al., 2013). With the temperature increasing from 200 to $350^{\circ} \mathrm{C}, \mathrm{Cd}$ sorption capacity increased from 31.9 to $51.4 \mathrm{mg} \cdot \mathrm{g}^{-1}$ as a result of the increased mineral content in biochar, especially the soluble carbonate (from $2.5 \%$ to $2.9 \%$ ). X-ray diffraction following Cd sorption evidenced that Cd-carbonate and phosphate formed in the biochar (Zhang et al., 2015). Moreover, Trakal et al. (2014) used Fourier transform-infrared spectroscopy (FT-IR) to follow Cd sorption on biochar with high ash content produced from grape husks and stalks. They suggested that surface precipitation of Cd-carbonate has shifted the peaks of carbonate. A similar mechanism can be found in the sorption of $\mathrm{Pb}$. Formation of $\mathrm{Pb}$-carbonate $\mathrm{Pb}_{3}\left(\mathrm{CO}_{3}\right)_{2}(\mathrm{OH})_{2}$ and $\mathrm{Pb}$-phosphate $\mathrm{Pb}_{9}\left(\mathrm{PO}_{4}\right)_{6}$ contributed most to the high removal rate of $\mathrm{Pb}$ (Cao et al., 2009).

\section{Organic contaminants}

It has been proved that biochar produced from biomaterials has favorable removal ability for organic contaminants (Gwenzi et al., 2017). In general, pore-filling, hydrophobic effect, electrostatic interaction, and hydrogen bonds are the main mechanisms of organic contaminants sorption by biochar, differing according to the physicochemical properties of the contaminants and biochar.

Pore-filling is an essential mechanism for the sorption of organic compounds on biochar. The sorption capacity is directly in proportion to the micropores' surface area (Han et al., 2013). Chen et al. (2012) revealed that the biochar's surface area is influenced by the pyrolysis temperature, affecting the uptake rate of naphthalene (NAP) in solutions. The organic components in the biomass were more completely carbonized at higher temperatures, so the biochar had a higher carbonization degree, larger surface area, and more developed micropores, leading to an enhanced sorption rate. Moreover, biochars produced at intermediate temperatures $\left(250-350^{\circ} \mathrm{C}\right)$ displayed relatively slow sorption rates, owing to the difficult pore-filling into certain highly condensed organic phases exited at these temperatures. Zhu et al. (2014) reported that the large surface area and pore volume of carbonaceous materials commonly promote the sorption of organic contaminants as a result of the pore-filling effect, which was also verified by research results of Inyang et al. (2014) and Han et al. (2013). 
200

201

202

203

204

205

206

207

208

209

210

211

212

213

214

215

216

217

218

219

220

221

222

223

224

225

226

227

228

229

230

231

232

233

234

235

236

237

238
Sun et al. (2013) explored the influence of deashing treatment on the biochar structure and its sorption ability for phenanthrene (PHE). They reported that after deashing, the hydrophobic domains of biochar increased while the polar functional groups decreased, bringing about more hydrophobic sorption sites for non-polar organic compounds, which promoted PHE sorption.

Also, they found that the hydrophobic effect was more significant for biochar prepared at higher temperatures. Ahmad et al. (2013) found that there was a more carbonized portion in the biochar produced under high pyrolysis temperature, resulting in better sorption for relatively hydrophobic trichloroethylene. As pyrolysis temperature increased, the hydrogen- and oxygencontaining functional groups were removed, leading to enhancement of the biochar's hydrophobicity, thus improving the sorption.

Different results also showed electrostatic interaction to be an essential mechanism of polar organic contaminant sorption (Inyang et al., 2014). Xu et al. (2011) investigated the sorption mechanism of Methyl Violet and found that electrostatic interaction, to be more specific, the attraction between dyes molecules with -COO- and phenolic -OH groups, promoted the sorption of Methyl Violet on biochar. Xie et al. (2014) stated that the sorption of sulfonamides (SAs) on different biochars is well correlated with the biochars' graphitization degree and the $\pi-\pi$ electron donor-acceptor (EDA) interaction existed between the graphitic surface ( $\pi$ electron donors) and SAs ( $\pi$ electron acceptors), accounting for the strong sorption.

Qiu et al. (2009) investigated the sorption mechanism of Brilliant Blue (BB) on straw-based biochar. It was suggested that the mechanism involved hydrogen bonds. FT-IR showed that after sorption, the intensity of the peak at $1795 \mathrm{~cm}^{-1}$ reflecting $\mathrm{C}=\mathrm{O}$ stretching vibration shifted little, and the peak at $3447 \mathrm{~cm}^{-1}$ corresponding to $-\mathrm{OH}$ stretching vibration had a bit change. There was a good chance that the intermolecular hydrogen bonds (O-H- - -O bonds) existed between the $\mathrm{H}$ atom in $-\mathrm{OH}$ of $\mathrm{BB}$ molecules and the $\mathrm{O}$ atom in $\mathrm{C}=\mathrm{O}$ on biochar surface, vice versa. The negatively charged properties for both biochar and $\mathrm{BB}$ also supported this weak interaction.

The co-existence of carbonized and non-carbonized proportions makes the biochar surface heterogeneous; meanwhile, the two types represent different sorption mechanisms. In addition to the sorption of organic compounds onto the carbonized proportion, the partition into the noncarbonized organic matrix is also essential when biochars are produced at lower temperatures (Zheng et al., 2010; Chen et al., 2012; Cao et al., 2009).

\section{Biochar application in water and wastewater treatment}

Among the increased number of published reports, biochar can be directly used in water and wastewater treatment as a sorbent for contaminants removal, or be used in constructed wetlands (CWs) and in the soil to improve the water quality. Table 1 compiled the references discussed 
239 within this section on the removal of various contaminants from water and wastewater by

240 biochar.

241

242 Industrial wastewater

243 As a dominant source of water contamination, the quantity of industrial wastewater and types of

244 water contaminants are booming due to the rapid development of the industry. Biochar is

245 becoming a new approach to remove various contaminants from industrial wastewater, both for

246 heavy metals and organic compounds.

247

248 Removal of $\mathrm{Cd}^{2+}, \mathrm{Pb}^{2+}, \mathrm{Cu}^{2+}, \mathrm{Hg}^{2+}, \mathrm{Cr}^{6+}$, and $\mathrm{Ni}^{2+}$ have received much attention due to the 249 adverse effects they could bring if released to the environment. Batch sorption experiments by 250 Zhou et al. (2013) showed that the biochar modified by chitosan had favorable removal 251 efficiency for three heavy metals $\left(\mathrm{Cd}^{2+}, \mathrm{Pb}^{2+}\right.$, and $\left.\mathrm{Cu}^{2+}\right)$ from solutions. Further research of $\mathrm{Pb}^{2+}$ 252 sorption implied that the biochar had a comparatively high Langmuir sorption capacity of 14.3 $253 \mathrm{mg} \cdot \mathrm{g}^{-1}$, despite the slow sorption kinetics. Boutsika et al. (2014) employed biochar produced 254 from malt spent rootlets (MSR) to remove $\mathrm{Hg}$ (II) from pure aqueous solutions. The removal 255 efficiency was up to $100 \%$ after a $24 \mathrm{~h}$ contact time at biochar concentrations of $1 \mathrm{~g} \cdot \mathrm{L}^{-1}$, with the 256 maximum $\mathrm{Hg}$ (II) sorption capacity of $103 \mathrm{mg} \cdot \mathrm{g}^{-1}$. Their later study showed that the $\mathrm{Hg}$ sorption 257 capacity by MSR biochars increased by a maximum factor of 6 for high-temperature $\left(750-900^{\circ} \mathrm{C}\right)$ 258 biochars compared to the raw material (Manariotis et al., 2015). Hg(II) sorption onto both 259 materials carried on mainly through neutral species (Boutsika et al., 2017). Shi et al. (2020) 260 developed a $\mathrm{ZnCl}_{2}$-modified glue residue biochar for $\mathrm{Cr}(\mathrm{VI})$ sorption. The maximum sorption 261 capacity reached $325.5 \mathrm{mg} \cdot \mathrm{g}^{-1}$, higher than the previously reported sorbents. Liu et al. (2014) 262 used zinc borate (ZB) as a flame retardant to prepare lotus stalks (LS) biochar for Ni(II) removal. 263 Sorption of Ni(II) on LS biochar was enhanced by 3-10 times compared with that of biochar 264 without adding ZB.

265

266 With the textile industry expanding rapidly, dye wastewater now accounts for a large proportion 267 of industrial wastewater. Among the methods of dye wastewater treatment, biochar sorption is 268 especially favored. For example, Pradhananga et al. (2017) reported that two dyes used in wool 269 carpet dyeing, Lanasyn Orange and Lanasyn Gray, could be highly sorbed on nanoporous 270 biochar derived from bamboo cane. The sorption capacity of both dyes was $2.6 \times 10^{3} \mathrm{mg} \cdot \mathrm{g}^{-1}$, 271 assuming pore-filling to be the primary sorption mechanism, and the high sorption capacity was 272 attributed to the high specific surface area $\left(2130 \mathrm{~m}^{2} \cdot \mathrm{g}^{-1}\right)$ and pore volume $\left(2.7 \mathrm{~cm}^{3} \cdot \mathrm{g}^{-1}\right)$ of 273 biochar. Researchers produced pecan nutshell biochar to remove Reactive Red 141 from water. 274 The biochar was claimed to be low-cost and environmentally friendly, which could be a 275 substitute for other conventional sorbents (Zazycki et al., 2018).

276

277 Emerging organic contaminants in industrial wastewater, such as phenols and PAHs, have gained 278 great concern. Dos Reis and Dias (2016) produced biochar from sewage sludge by pyrolysis at 
279

280

281

282

283

284

285

286

287

288

289

290

291

292

293

294

295

296

297

298

299

300

301

302

303

304

305

306

307

308

309

310

311

312

313

314

315

316

317

$500^{\circ} \mathrm{C}$, followed by $\mathrm{HCl}$ treatment. The biochar displayed a very high sorption capacity for hydroquinone, which was up to $1218.3 \mathrm{mg} \cdot \mathrm{g}^{-1} . \pi-\pi$ EDA interactions play significant roles in the sorption. Valili et al. (2013) reported that the MSR biochar pyrolyzed at a higher temperature of $800^{\circ} \mathrm{C}$ gained a much higher PHE sorption capacity, two orders of magnitude higher compared to the raw material. Chen and Chen (2009) made orange peel biochar with a pyrolysis temperature ranging from 150 to $700^{\circ} \mathrm{C}(\mathrm{OP} 150-\mathrm{OP} 700)$ for sorption of 1-naphthol and NAP. For biochars pyrolyzed at lower temperatures, their polar surface due to the presence of water molecules has additional polar interactions (e.g., hydrogen bonds) with 1-naphthol, resulting in higher sorption capacity than NAP. Meanwhile, the partition is favored as the sorbate concentration increases, but adsorption rapidly reaches saturation (Chen et al., 2008). OP200 had the maximal sorption capacity for 1-naphthol with high concentration due to polar interactions and high partition. However, OP700 exhibited an optimum sorption capacity for NAP because of its highest surface area and low surface polarity, which facilitated the NAP sorption.

\section{Pesticides}

Utilization of pesticides benefits the agricultural production and the economy, but excessive use of pesticides causes toxicity on non-target organisms and destruction to ecological balance and human health (Zhong, 2018). Biochar is applied as a distinctive remediation method in pesticide contamination treatment (Dai et al., 2019).

Zhang et al. (2018) produced maize straw biochar at 300,500 , and $700^{\circ} \mathrm{C}$ to study thiacloprid sorption. They found that the sorption occurred probably via pore-filling, hydrophobic interaction, and $\pi-\pi$ interaction. Jin et al. (2016) prepared biochar by pyrolysis of swine manure at $600^{\circ} \mathrm{C}$, which was used for imidacloprid sorption. The results showed that pore-filling is likely one of the dominant sorption mechanisms for this kind of polar chemical. Klasson et al. (2013) prepared almond shell biochar by pyrolysis with steam treatment. The biochar had a larger specific surface area of $344 \mathrm{~m}^{2} \cdot \mathrm{g}^{-1}$ and a sorption capacity of $102 \mathrm{mg} \cdot \mathrm{g}^{-1}$ for dibromochloropropane, a nematode insecticide, and the field experiment was carried out successfully.

Zheng et al. (2010) investigated the sorption of two triazine pesticides, atrazine and simazine on biochar. Based on different sorption conditions, the sorption ability of atrazine was 451-1158 $\mathrm{mg} \cdot \mathrm{g}^{-1}$, and $243-1066 \mathrm{mg} \cdot \mathrm{g}^{-1}$ for simazine. When the two sorbates existed synchronously, there was competitive sorption on biochar. The sorption capacity of atrazine was $435-286 \mathrm{mg} \cdot \mathrm{g}^{-1}$, and 514-212 $\mathrm{mg} \cdot \mathrm{g}^{-1}$ for simazine. The study also reported that the sorption process of both single and multiple triazine pesticides on biochar could be well explained by surface sorption mechanism. Uchimiya et al. (2010) produced broiler litter biochar by pyrolysis at 350 and $700^{\circ} \mathrm{C}$ to remove deisopropylatrazine, a stable metabolite of atrazine from water. They found that the biochar prepared at $700^{\circ} \mathrm{C}$ had higher surface area, more micropores in non-carbonized fraction, and 
318 greater aromaticity. Thus, the target contaminant can be effectively removed, while the removal 319 efficiency of biochar prepared below $500^{\circ} \mathrm{C}$ was relatively low.

320

321

322

323

324

325

326

327

328

329

330

331

332

333

334

335

336

337

338

339

340

341

342

343

344

345

346

347

348

349

350

351

352

353

354

355

356

357

\section{Antibiotics}

Some antibiotics in pharmaceutical wastewater are difficult to decompose in the natural environment and regarded as emerging environmental contaminants (Carvalho \& Santos, 2016). Reducing the toxicity of antibiotics by biochar becomes a hot spot.

Tetracyclines (TCs) and SAs are two of the most commonly used antibiotics and are also used in intensive agriculture as feed additives, bringing potential hazards to the environment and human health when extensively used (Yu et al., 2016; Shao et al., 2005). The removal of TCs by $\mathrm{ZnCl}_{2} / \mathrm{FeCl}_{3}$ solution doped sawdust biochar was studied systematically. Results showed that this kind of biochar had the potential ability for TCs removal in water, with the removal rate above $89 \%$ after three cycles (Zhou et al., 2017). Peiris et al. (2017) made a further study on the sorption mechanisms of SAs on biochar. Generally, high-temperature produced biochar showed high sorption quantity under the condition of weak acidity, attributed to strong $\pi-\pi$ EDA interactions between the abundant arene rings on the biochar surface and SAs molecules. Micropore-filling is also a common mechanism because of the smaller size of SAs. Zhao et al. (2019) prepared humic acid-coated magnetic biochar derived from potato stems and leaves to sorb three typical fluoroquinolones (FQs) - enrofloxacin (ENR), norfloxacin (NOR), and ciprofloxacin (CIP). The maximum adsorption capacities were $8.4 \mathrm{mg} \cdot \mathrm{g}^{-1}$ for ENR, $10.0 \mathrm{mg} \cdot \mathrm{g}^{-1}$ for NOR, and $11.5 \mathrm{mg} \cdot \mathrm{g}^{-1}$ for CIP. High FQs removal efficiency could be owing to hydrophobic, electrostatic and $\pi-\pi$ EDA interactions and formation of hydrogen bonds.

\section{Indicator organisms and pathogens}

Biochar application in the removal of indicator organisms and pathogens mainly aims at the treatment of urban stormwater runoff, which contains a wide range of contaminants and eventually runs into surface water (e.g., streams, lakes). Irrigation with these contaminated waters can lead to microbial contamination of vegetables. Biochar filters for microbe removal from water have received considerable attention.

Kaetzl et al. (2019) studied the filtration of rice husk biochar and non-pyrolyzed rice husk as low-cost filter materials for wastewater and evaluated their potential and limitation. In general, the performance of the biochar filter was superior or equal to the rice husk and standard sand filters. The treated wastewater was then used in a pot test for lettuce irrigation. Results showed that the contamination with fecal indicator bacteria was $>2.5 \log$ units lower than the control group irrigated with untreated wastewater. Mechanisms responsible for the removal include the filtration of larger pathogens and the sorption of negatively charged bacterial and cells (Gwenzi et al., 2017). Similarly, Perez-Mercado et al. (2019) showed that by using biochar as a filter medium, $>1 \log _{10}$ CFU Saccharomyces cerevisiae was successfully removed from diluted 
358

359

360

361

362

363

364

365

366

367

368

369

370

371

372

373

374

375

376

377

378

379

380

381

382

383

384

385

386

387

388

389

390

391

392

393

394

395

396

wastewater under the condition of on-farm irrigation. The particle size of biochar is the main influencing factor accounting for the microbial removal efficiency. The minimum particle size $\left(\mathrm{d}_{10}=1.4 \mathrm{~mm}\right)$ could consistently remove at least $1 \log _{10} \mathrm{CFU}$ of most target microbes. More micropores and smaller pore size of biochar could increase straining effect and contact time between bacteria and sorption sites. Mohanty et al. (2014) improved sand biofilters with $5 \mathrm{wt} \%$ biochar amended to increase the bacteria removal capacity. The biochar-amended sand filter retained up to three orders of magnitude more Escherichia coli and prevented their mobility during continuous, intermittent flows. The improved removal capacity of pathogens was attributed to higher retention on the biochar filter, which increased the attachment of $E$. coli.

\section{Inorganic ions}

In virtue of the convenience and little generation of secondary contamination (Yang et al., 2018; Yin et al., 2017), biochar are popular in inorganic ions removal, which targets at the removal of nutrient elements $\mathrm{N}$ and $\mathrm{P}$ that exist in the form of inorganic ions in wastewater, and $\mathrm{F}^{-}$in drinking water.

Fan et al. (2019) conducted a study on $\mathrm{NH}_{4}{ }^{+}$sorption by hydrous bamboo biochar. Results found that the biochar had a sufficient sorption capacity for $\mathrm{NH}_{4}^{+}$, with a maximum of $6.4 \mathrm{mM} \cdot \mathrm{g}^{-1}$. The sorption was enhanced at higher ionic strength conditions, indicating that physical reactions possibly made contributions to the sorption process such as electrostatic interactions. Potential mechanisms for $\mathrm{NH}_{4}{ }^{+}$sorption was further studied by Hu et al. (2020). They reported that $\mathrm{pH}$ influenced the $\mathrm{NH}_{4}{ }^{+}$sorption capacity by changing the surface charge of biochar. Negatively charged biochar in higher $\mathrm{pH}(\mathrm{pH}>\mathrm{pH}$ PZC $)$ solutions easily sorbed $\mathrm{NH}_{4}{ }^{+}$due to electrostatic attraction. FT-IR patterns showed that the $-\mathrm{OH}$ and $-\mathrm{C}=\mathrm{O}$ groups weakened after the sorption, indicating that the $\mathrm{NH}_{4}{ }^{+}$acted with these functional groups through surface complexation. In addition, ion exchange between $\mathrm{NH}_{4}{ }^{+}$and the negatively charged functional groups such as $-\mathrm{OH}$ and - $\mathrm{COOH}$ also led to the $\mathrm{NH}_{4}^{+}$sorption. For $\mathrm{NO}_{3}{ }^{-}$, the sorption mechanisms are governed by multiple interactions, primarily electrostatic attraction, and ionic bonds with exchangeable cations from the biochar, based on the sorption study of $\mathrm{NO}_{3}{ }^{-}$by bamboo biochar (Viglašová et al., 2018).

Walnut shell and sewage sludge were co-pyrolyzed to prepare biochar for $\mathrm{PO}_{4}{ }^{3-}$ sorption from eutrophic water (Yin et al., 2019). The biochars exhibited ideal sorption ability, among which the pure sewage sludge biochar had the maximum sorption capacity of $303.5 \mathrm{mg} \cdot \mathrm{g}^{-1}$ in a wide $\mathrm{pH}$ range and was the best option for $\mathrm{PO}_{4}{ }^{3-}$ sorption among the biochars. Ajmal et al. (2020) compared the removal efficiency of $\mathrm{PO}_{4}{ }^{3-}$ from wastewater by biochars before and after magnetic modification. Results showed that the sorption ability of magnetic biochar was twice $\left(25-28 \mathrm{mg} \cdot \mathrm{g}^{-1}\right)$ than that of the unmodified biochar $\left(12-15 \mathrm{mg} \cdot \mathrm{g}^{-1}\right)$. The $\mathrm{PO}_{4}{ }^{3-}$ sorption on magnetic biochar is dominated by simultaneous mechanisms including electrostatic attraction, 
397

398

399

400

401

402

403

404

405

406

407

408

409

410

411

412

413

414

415

416

417

418

419

420

421

422

423

424

425

426

427

428

429

430

431

432

433

434

435

436

surface precipitation, and complexation, while for the original biochar, the sorption mainly depends on electrostatic attraction.

$\mathrm{F}^{-}$is characterized by high electronegativity and small ionic size, resulting in a strong affinity towards metal ions such as $\mathrm{Al}(\mathrm{III}), \mathrm{La}(\mathrm{III})$, and Fe(III) (Wu et al., 2007). Thus, a strong $\mathrm{F}^{-}$ sorption could be achieved by composites made of such metal ions dispersing in a porous matrix such as biochar. Such a study was made by Tchomgui-Kamga et al. (2010), which found that the Al-modified spruce wood biochar had a maximum removal capacity of $13.6 \mathrm{mg} \cdot \mathrm{g}^{-1}$ for $\mathrm{F}^{-}$. The dispersion of $\mathrm{Al}$ into the porous structure of biochar significantly increased the sorption. The Langmuir isotherm model served as the most suitable model for $\mathrm{F}^{-}$sorption (Ahmed et al., 2016).

\section{Indirect water and wastewater treatment}

In recent years, CWs have been widely used in wastewater treatment, including removal of $\mathrm{N}, \mathrm{P}$ (Li et al., 2019), and some organic contaminants. Nevertheless, due to restricted oxygen supply and transport capacity, limited sorption capacity of the substrate, and inhibition of microbes and plants metabolism at low temperatures, the removal efficiency for $\mathrm{N}$ and $\mathrm{P}$ is severely hindered (Ying et al., 2010). Researchers have attempted to explore particular substrates to intensify the functions of CWs with high contaminants concentration, among which biochar has been favorably considered (Gupta et al., 2015).

Zhou et al. (2018) used biochar as a substrate in vertical flow constructed wetlands (VFCWs) to enhance the removal efficiency with a series of low $\mathrm{C} / \mathrm{N}$ ratio influent strengths. They assessed the removal of $\mathrm{N}$ and organic contaminants in both VFCWs with/without biochar added. Results showed that the average removal rates of $\mathrm{NH}_{4}-\mathrm{N}(39 \%)$, $\mathrm{TN}(39 \%)$, and organic contaminants $(85 \%)$ were better than those of conventional VFCWs, especially for the high-strength wastewater. A seven-month study by Bolton et al. (2019) clearly showed that enriched biochar was a suitable substrate for $\mathrm{PO}_{4}-\mathrm{P}$ removal. The waste biochar has the potential for regeneration, which can be applied as soil fertilizer to improve soil quality, while this application still needs more investigations. Deng et al. (2019) set up four subsurface flow constructed wetlands (SFCWs) with biochar amended in standard gravel at different volume ratios (0-30\%). Results indicated that the removal rates of $\mathrm{NH}_{4}-\mathrm{N}$ and $\mathrm{TN}$ by SFCWs with biochar were higher than those by pure gravel-filled SFCWs. The additive of biochar promotes $\mathrm{N}$ removal by changing the structure of microbial communities and increasing the abundance of dominant species. Besides, biochar improves the metabolism of high molecular compounds and convert them into low molecular compounds. These results provide new insights into strengthening $\mathrm{N}$ removal through microbial metabolism with the effect of biochar.

Surface runoff and soil erosion in the river basin, especially in some degraded fields with high precipitation, could cause certain contamination to the water environment. Several studies have proved that biochar has the potential to reduce surface runoff and soil erosion (Razzaghi et al., 
437 2020; Głąb et al., 2020; Bayabil et al., 2015; Tanure et al., 2019; Gholami et al., 2019). Biochar 438 particles can bond with soil mineral surface through phenolic and carboxylic functional groups, 439 thus improve the stability of soil aggregation and structure (Soinne et al., 2014). Besides, the 440 exchangeable divalent cations with high charge density (e.g., $\mathrm{Ca}^{2+}, \mathrm{Mg}^{2+}$ ) on biochar surface can 441 replace the monovalent cations (e.g., $\mathrm{Na}^{+}, \mathrm{K}^{+}$) on exchange sites of clay particles, which

442 enhances clay flocculation and thereby improves macropores size and network in the soil (Rao \& 443 Mathew, 1995), eventually increases the infiltration capacity. Therefore, it is concluded that the 444 biochar amendment can improve soil physical properties, which in turn reduces runoff, erosion, 445 and waterlogging (Bayabil et al., 2015). Moreover, biochar with large water-storing property 446 spreading on soil surface could absorb the force of raindrops, thus increases the runoff time 447 (Gholami et al., 2019).

448

\section{Biochar modification}

474

475

Although biochar has been extensively applied in the removal of diversiform contaminants in

476

\section{Current application of biochar in wastewater treatment facilities}

Although biochar exhibits some similar properties as the activated carbon, it is a more heterogeneous material with many uncertainties when applied in engineered facilities (Gwenzi et al., 2017). Situations involving ion strength, $\mathrm{pH}$, or presence of organic matters make the sorption more complex. Compared with current wastewater treatment facilities with mature technologies, which usually use activated sludge, activated carbon, and a series of water treatment agents such as flocculants and disinfectants, there are limited attempts to develop biochar-based wastewater treatment facilities. Despite the published efforts on the removal of various contaminants by biochar, the studies are based on laboratory batch experiments. Operation parameters and conditions for real facilities remain lacking.

To date, biochar-based filters have been an attempt to advance the engineered application of biochar. Sand filters and biofilters amended with biochar (Kaetzl et al., 2019; Perez-Mercado et al., 2019), and filters made of biochar-clay composite (Chaukura et al., 2020), all have shown the improvements in wastewater treatment performance. Notably, a pilot-scale biochar-based wastewater treatment system called N-E-W Tech ${ }^{\mathrm{TM}}$ was built and patented by Greg Möller from the University of Idaho in 2015 (https://www.lib.uidaho.edu/digital/uinews/item/n-e-w-techproject-proposes-better-water-treatment-system.html). This system promises highly efficient removal of phosphorus and mineral contaminants from wastewater; meanwhile, it makes use of the minerals stripped from water to produce fertilizer, which is also cost-effective. The system was then licensed and promoted in real wastewater treatment systems in the USA, England, and South Korea. This case demonstrates the scalability of biochar engineered application and provides guidance as well. water solutions, its applicability is limited because of the lower removal efficiency for some selected contaminants or in some specific water conditions. The unmodified biochars have much 
477 lower removal ability than the modified ones, especially in high-strength wastewater ( $\mathrm{S} \& \mathrm{P}$, 478 2019). Researchers have found relationships between the surface area and functionality of 479 biochar with the sorption capacity (Tan et al., 2015; Goswami et al., 2016). More micropores and 480 mesopores correspond to larger surface area and more sorption sites where contaminants can be 481 sorbed (Sizmur et al., 2017). Accordingly, the modification of biochar generally concerns (i) 482 increasing the surface area and porosity; (ii) enhancing the surface properties; (iii) embedding 483 other materials into the biochar matrix to obtain beneficial composites (Sizmur et al., 2017).

484 According to different modification emphases, modification methods of biochar are summarized 485 in Figure 2.

486

\section{Increasing surface area and porosity}

In general, biochar with larger surface area has more sorption sites, facilitating the sorption

489

490

491

492

493

494

495

496

497

498

499

500

501

502

503

504

505

506

507

508

509

510

511

512

513

514

515 capacity. Plenty of modification methods of biochar have been proposed to achieve this favorable property.

Physical modification usually uses gases such as $\mathrm{CO}_{2}$ (Guo et al., 2009) and steam (Shim et al., 2015 ) to treat biochar at the temperature over $700^{\circ} \mathrm{C}$. With steam treatment, the incomplete combustion components are removed, and the porosity is improved, both of which increase the sorption sites. Lima and Marchall (2005) pyrolyzed poultry manure at $700^{\circ} \mathrm{C}$ to produce biochar, followed by a series of steam with different water flow rates and durations at $800^{\circ} \mathrm{C}$. Results showed that longer action times and higher flow rates increased the sorption of $\mathrm{Zn}, \mathrm{Cu}$, and $\mathrm{Cd}$ on the biochar surface. Zhang et al. (2004) investigated the effect of $\mathrm{CO}_{2}$ treatment duration on biochars derived from corn stover, corn hulls, and oak wood waste. All biochars exhibited higher sorption capacity with longer treating duration owing to the larger surface area and micropore volume. Kangyi Lou (2016) claimed that the steam treatment had no significant effect on surface functional groups on biochar. Therefore, the steam treatment appears to be more efficient if it is used before a second modification step, which can increase the number of surface functional groups (Sizmur et al., 2017).

Acidic or alkaline treatment also increases the surface area. Zhao et al. (2017) treated pine tree sawdust with diluted $\mathrm{H}_{3} \mathrm{PO}_{4}$ before pyrolysis. Both the total surface area and pore volume increased after the treatment, and the sorption capacity for $\mathrm{Pb}$ increased by more than $20 \%$ because of surface sorption and phosphate precipitation. Goswami et al. (2016) proved that pyrolyzing the biochar- $\mathrm{KOH}$ mixture at $350-550^{\circ} \mathrm{C}$ reopened some of the blocked pores, and expanded the pore size of smaller pores, increasing the surface area and Cd sorption from the water via surface complexation. Hamid et al. (2014) reported that the increase of surface area resulting from $\mathrm{KOH}$ modification also increased the sorption of oxyanions. For that, Jin et al. (2014) proposed that the maximum $\mathrm{As}(\mathrm{V})$ sorption on biochar modified by $\mathrm{KOH}$ increased from $24 \mathrm{mg} \cdot \mathrm{g}^{-1}$ to $31 \mathrm{mg} \cdot \mathrm{g}^{-1}$, as a result of increased surface area. Similarly, researchers found a larger 
516 surface area and iodine sorption capacity of both the feedstock and biochar when the

517 modification was conducted by mixing with solid $\mathrm{NaOH}$ (Pietrzak et al., 2014).

518

519 Except for the physical, acidic, and alkaline modification mentioned above, some of the biochar-

520 based composites also possess a larger surface area by impregnating biochar with specific

521 materials. In this case, the biochar primarily plays a role as a scaffold with high surface area on

522 which other materials are deposited (Sizmur et al., 2017). Chen et al. (2017) pointed out that the

523 additive of montmorillonite during the pyrolysis of bamboo powder led to an increase in surface

524 area and porosity, partially as a result of the existence of layered montmorillonite, which

525 contributed to better sorption capacities for $\mathrm{NH}_{4}{ }^{+}$and $\mathrm{PO}_{4}{ }^{3-}$. Yao et al. (2014) observed the

526 layered surface of clay modified biochar through scanning electron microscope (SEM), similar to

527 a typical clay structure morphology.

528

529

\section{Increasing positive surface charge}

530 Generally, the surface charge of biochar is negative and has a higher $\mathrm{pH}$ value, making biochar

531 an excellent sorbent of metal cations, while a poor sorbent for oxyanions such as $\mathrm{NO}_{3}{ }^{-}, \mathrm{PO}_{4}{ }^{3-}$,

532 and $\mathrm{AsO}_{4}{ }^{3-}$ (Sizmur et al., 2017). Thus, modifications usually use the porous surface of biochar

533 as a scaffold for embedding positively charged metal oxides. The obtained composites can

534 remove oxyanions with negative charge from water (Sizmur et al., 2017).

535

536

Most methods to prepare biochar-metal oxide composites aim to assure the homogeneous

537 distribution of metals on biochar surface. Biochar here plays a role as porous carbon support

538 where the metal oxides precipitate to gain more positive surface charge and surface area

539 simultaneously. In general, biochar or raw materials soaked into metal chloride or nitrate

540 solutions $\left(\mathrm{MgCl}_{2}, \mathrm{FeCl}_{3}\right.$, and $\left.\mathrm{Fe}\left(\mathrm{NO}_{3}\right)_{3}\right)$ are most frequently used to realize the attachment of

541 metals. After heating under atmospheric conditions at $50-300^{\circ} \mathrm{C}$, the chlorides or nitrates were

542 driven off as $\mathrm{Cl}_{2}$ and $\mathrm{NO}_{2}$ gases, and the metal ions were converted into metal oxides (Sizmur et al., 2017). Zhang et al. (2012) used several common biomass wastes to create biochar-MgO composites by mixing the feedstocks with $\mathrm{MgCl}_{2}-6 \mathrm{H}_{2} \mathrm{O}$ solution and then pyrolyzing. SEM images showed that $\mathrm{MgO}$ particles were uniformly spread on the biochar surface. The maximum sorption capacity for nitrogen and phosphorus from sewage reached 95 and $835 \mathrm{mg} \cdot \mathrm{g}^{-1}$, respectively, due to positively charged $\mathrm{MgO}$ that precipitated onto the biochar. They also produced biochar $/ \mathrm{MgAl}$-layered double hydroxides by mingling cotton stalk with a mixed solution of $\mathrm{AlCl}_{3}-6 \mathrm{H}_{2} \mathrm{O}$ and $\mathrm{MgCl}_{2}-6 \mathrm{H}_{2} \mathrm{O}$ (Zhang et al., 2013). The maximum sorption capacity

550

551 for phosphorus increased by 5-50 times. composites, which can improve the sorption of both metal cations and oxyanions in water solutions. Jellali et al. (2016) explored the effects of Mg modification on sorption ability for metal cations. In this study, $\mathrm{Pb}$ sorption by a cypress sawdust-derived and $\mathrm{MgCl}_{2}$-treated biochar 
556

557

558

559

560

561

562

563

564

565

566

567

568

569

570

571

572

573

574

575

576

577

578

579

580

581

582

583

584

585

586

587

588

589

590

591

592

593

594

was investigated. Results showed that the modified biochar obtained an enhanced sorption capacity, about 7.4 times more compared to the raw material.

In general, the sorption of oxyanions by biochar-metal oxide composites arises from electrostatic attraction or chemical sorption with positively charged metal oxides in the biochar matrix (Zhou et al., 2014; Ren et al., 2015), while the sorption of metal cations is caused by co-precipitation occurring in the metal oxides lattice, or chemical sorption on oxygen-containing functional groups on the biochar's unmodified part (Tan et al., 2015). Rajapaksha et al. (2016) suggested that even though most modifications by metal oxides decreased the surface area because of poreclogging with metal oxide precipitates, the modifications eventually increased the sorption capacity owing to the formation of $\mathrm{pH}$-dependent bonds with positively charged functional groups on the biochar surface.

\section{Increasing surface oxygen-containing functional groups}

The biochar surface contains several functional groups such as carboxyl, hydroxyl, and phenolic groups, which are capable of chemically binding with contaminants and remove them from aqueous solutions.

The acidic treatment provides additional oxygen-containing functional groups on the biochar surface and increases the potential of chemically binding with positively charged contaminants via specific sorption. The biochar forms carboxylic groups on its surface when exposed to acidic solutions (Qian et al., 2013; Hadjittofi et al., 2014). Hadjittofi et al. (2014) used $\mathrm{HNO}_{3}$ to modify biochar produced from cactus fibers to obtain more surface carboxylic groups as sorption sites for metal cations $\left(\mathrm{Cu}^{2+}\right.$ and $\left.\mathrm{Pb}^{2+}\right)$. The sorption capacity at $\mathrm{pH} 6.5$ was an order of magnitude larger than that at $\mathrm{pH} 3$, indicating the $\mathrm{pH}$-dependent and chemical sorption on oxygencontaining functional groups. Qian et al. (2013) suggested that after the treatment in a mixture of $\mathrm{H}_{2} \mathrm{SO}_{4}$ and $\mathrm{HNO}_{3}$, the $\mathrm{O} / \mathrm{C}$ ratio of rice straw biochar was higher in the final product, implying that oxygen-containing functional groups were enriched in the structure of biochar.

Since biochar modification by strong acids is costly in a large-scale application and causes environmental concerns when disposing of the modification agents, researchers have made efforts to come up with cheaper and cleaner oxidants as alternatives to modify biochar. Song et al. (2014) pyrolyzed corn straw at $600^{\circ} \mathrm{C}$ and then mixed it with $\mathrm{KMnO}_{4}$ solution. $\mathrm{A} \mathrm{MnO}_{\mathrm{x}}$ biochar was prepared after another pyrolysis. Compared with the original biochar, the $\mathrm{O} / \mathrm{C}$ ratio increased from about 0 to 0.5 . XPS analyses showed that the increased oxygen existed mainly in the $\mathrm{Mn}-\mathrm{OH}$ and $\mathrm{Mn}-\mathrm{O}$ structure, which primarily accounted for the enhanced sorption ability for $\mathrm{Cu}^{2+}$ (from 19.6 to $160.3 \mathrm{mg} \cdot \mathrm{g}^{-1}$ ). Huff and Lee (2016) showed an increased number of oxygencontaining functional groups on the biochar surface after treatment using $\mathrm{H}_{2} \mathrm{O}_{2}$. The cation exchangeability of the biochar was almost doubled than that of the untreated one, as a result of 
595 cation exchange on the more abundant oxygen-containing functional groups on the modified 596 biochar surface.

597

598

599

600

601

602

603

604

605

606

607

608

609

610

611

612

613

\section{4}

615

616

617

618

619

620

621

622

623

624

625

626

627

628

629

630

631

632

633

634

Alkaline solutions play a similar role to acids and oxides in increasing the number of oxygencontaining functional groups on the biochar surface. Jin et al. (2014) reported that $\mathrm{KOH}$ modification of biochar made of municipal solid wastes enhanced the $\mathrm{As}(\mathrm{V})$ sorption performance, not only because of the increased surface area but also the growing number of surface oxygen-containing functional groups, which provided proton-donating exchange sites where metal cations can be chemically sorbed (Petrović et al., 2016).

Among various biochar-based composites, the biochar-graphene oxide composite material, which is obtained by impregnating the raw material in a graphene oxide suspension and then pyrolyzing, also displays more oxygen-containing functional groups after incorporating the graphene structure (Tang et al., 2015; Shang et al., 2016). The removal rate of $\mathrm{Hg}^{2+}$ raised with the increase of the proportion of graphene oxide in the composite. When the maximum percentage of graphene oxide is $1 \%$, the removal rate of the composite was $8.7 \%$ more than that of the unmodified biochar. FT-IR showed that the abundant oxygen-containing functional groups dominate the sorption behavior of $\mathrm{Hg}^{2+}$ on the biochar-graphene oxide composite.

\section{Incorporating surface amino functional groups}

Incorporating amino functional groups onto the biochar surface improves the sorption ability through inducing strong complexation between contaminants and the amino sites. The modification is obtained either by chemical reactions or blending biochar with amino-rich polymers such as polyethyleneimine (PEI) and chitosan (Zhou et al., 2013; Zhou et al., 2014; Yang \& Jiang, 2014).

Yang and Jiang (2014) used $\mathrm{HNO}_{3}, \mathrm{H}_{2} \mathrm{SO}_{4}$, and $\mathrm{Na}_{2} \mathrm{~S}_{2} \mathrm{O}_{4}$ to modify biochar via nitration and reduction reactions as a selective and efficient sorbent for $\mathrm{Cu}^{2+}$. Although there was little significant difference in the physical structure before and after the modification, attenuated total reflectance FT-IR and XPS results showed that the amino groups chemically bound with the functional groups on the biochar surface. The amino modification made the sorption capacity for $\mathrm{Cu}^{2+}$ increased by five times. Ma et al. (2014) used PEI to prepare amino-rich biochar to remove $\mathrm{Cr}(\mathrm{VI})$ from aqueous solutions, which obtained a much higher maximum sorption capacity $\left(435.7 \mathrm{mg} \cdot \mathrm{g}^{-1}\right)$ than that of the unmodified biochar $\left(23.1 \mathrm{mg} \cdot \mathrm{g}^{-1}\right)$.

Zhou et al. (2013) synthesized chitosan-modified biochars derived from peanut hull, hickory wood, sugarcane bagasse, and bamboo, aiming to provide a commercial sorbent for heavy metals remediation in the water environment. Characterization of the biochars showed that the chitosan coating on the biochar surface improved the surface properties. Batch sorption experiments stated that the removal abilities for $\mathrm{Cd}^{2+}, \mathrm{Cu}^{2+}$, and $\mathrm{Pb}^{2+}$ in aqueous solutions by almost all 
635 chitosan-modified biochars were enhanced, compared with the unmodified biochars. Further 636 studies of $\mathrm{Pb}$ sorption on chitosan-modified bamboo biochar found that, even though the sorption

637 kinetics were slow, the modified biochar had a relatively high Langmuir $\mathrm{Pb}$ sorption capacity of $63814.3 \mathrm{mg} \cdot \mathrm{g}^{-1}$, significantly reducing the toxicity of $\mathrm{Pb}$. Characterization of the $\mathrm{Pb}$-loaded biochar 639 after sorption exhibited that the sorption of $\mathrm{Pb}$ is primarily caused by the interaction with amino 640 functional groups on the biochar surface.

641

642 Magnetization

643 The magnetization of biochar is a new modification frontier. It develops in situations where the 644 separation of biochar from aqueous solutions face great difficulties. The application of a magnet 645

646

647 Impregnation-pyrolysis and co-precipitation are the most commonly used preparation method for 648 magnetic biochar, accounting for about $69.6 \%$ of all preparation methods (Yi et al., 2020).

649 Impregnation-pyrolysis is to impregnate the suspension of biochar with a solution of transition 650 metal salts, followed by pyrolysis of the residue. In this way, Mohan et al. (2014) produced 651 magnetic biochar using $\mathrm{Fe}^{3+} / \mathrm{Fe}^{2+}$ solution. It was found that the iron content increased from $6521.4 \%$ to $80.6 \%$, indicating that the biochar was effectively magnetized. In the application of $\mathrm{Pb}^{2+}$ 653 and $\mathrm{Cd}^{2+}$ removal from solutions, the biochar showed significantly higher sorption capacity.

654 Except for conventional pyrolysis, microwave heating is extensively applied in the synthesis of 655 magnetic biochar. Dos Reis and Dias (2016) produced biochars in different methods - pyrolysis 656 at $500^{\circ} \mathrm{C}$ and microwave heating under an inert atmosphere - both were followed by $\mathrm{HCl}$ treatment. The biochars had approximately equal and very high sorption capacity for hydroquinone, showing that microwave heating could be an alternative to conventional pyrolysis. The co-precipitation synthetic pathway includes the dispersion of biochar in a solution of transition metal salts, adjusting the $\mathrm{pH}$ to $9-11$ with $\mathrm{NaOH}$ or ammonia solution with constant stirring. Magnetic biochar is obtained by drying the residue (Yi et al., 2020). Yu et al. (2013) obtained magnetic biochar by mixing $\mathrm{Fe}^{2+} / \mathrm{Fe}^{3+}$ solution into an ammonia solution with biochar particles dispersed, followed by ultrasound irradiation at $60^{\circ} \mathrm{C}$. The magnetic biochar exhibited an increased number of carboxyl functional groups on the surface, resulting in a more negatively charged property, which improved the sorption rate and capacity for heavy metal ions.

669

670

671

672

673

674

In addition to surface functional groups that take effects in the sorption process, the magnetic components which exist in the main forms of $\mathrm{Fe}_{2} \mathrm{O}_{3}, \mathrm{Fe}_{3} \mathrm{O}_{4}, \mathrm{FeO}$, and $\mathrm{Fe}^{0}$, also play an important role in improving the sorption ability (Yi et al., 2020). For example, $\mathrm{Fe}^{0}$ makes vital contributions to $\mathrm{Pb}$ (II) removal by directly reduction (Chen et al., 2018), while $\mathrm{Fe}_{3} \mathrm{O}_{4}$ plays a crucial role in remediation of $\mathrm{Cr}(\mathrm{VI})$, attributed to the $\mathrm{Fe}(\mathrm{II})$ and $\mathrm{Fe}(\mathrm{III})$ in octahedral coordination in $\mathrm{Fe}_{3} \mathrm{O}_{4}$, which act as active chemical sorption or reduction sites (Zhong et al., 2018). Synthetic conditions such as pyrolysis temperature influence the morphology of magnetic components, for instance, the $\mathrm{Fe}_{3} \mathrm{O}_{4}$ in magnetic biochar transformed into $\mathrm{FeO}$ when the 
675 pyrolysis temperature increased (Chen et al., 2019). Moreover, innovative synthetic methods that 676 introduce other metals such as $\mathrm{Cu}, \mathrm{Zn}$, and $\mathrm{Mn}$ lead to the formation of magnetic substances 677 containing these metals, playing a particular role in enhancing the removal effect (Zhang et al., 678 2019; Heo et al., 2019).

679

680

681

682

683

684

685

686

687

688

689

690

691

692

693

694

695

696

697

698

699

700

701

702

703

704

705

706

707

708

709

710

711

712

713

\section{Biofilm formation}

Taking advantage of the high surface area, porosity, and inert property, biochar can be used as a scaffold for colonization and growth of biofilms. The microbes adhere to the biochar surface and develop an extracellular biofilm by secreting multiple polymers as an adhesive, and therefore have stronger viability owing to the protection from the biofilm, excelling the traditionally separate microbial treatment (Hall-Stoodley et al., 2004). In such biotic systems, biochar plays its role in the sorption of contaminants by the porous structure and surface functional groups, while the microbes promote the degradation of resistant compounds owing to their metabolism (Singh et al., 2006). The synergistic removal effect makes such biotic biochar be increasingly used in water and wastewater treatment.

The primary purpose of biochar with biofilm is to promote the biodegradation of organic contaminants (Sizmur et al., 2017). Dalahmeh et al. (2018) studied the potential of biochar filters with biofilm as a substitution or progress of conventional sand filters for contaminants removal from pharmaceutical wastewater. For carbamazepine, the biotic biochar possessed more effective and stable removal efficiency than sand filters, more than $98 \%$ over the 22 weeks of operation. The combination of sorption and simultaneous biodegradation are conducive to the removal. Frankel et al. (2016) proved the synergistic behavior by biofilm and biochar in naphthenic acid (NA) removal from water solutions. The biotic biochar had a higher NA removal rate $(72 \%)$ than either the sterile biochar (22-28\%) or the microbes alone (31-43\%). Interestingly, in the presence of metals ( $\mathrm{Al}$ and $\mathrm{As}$ ), although there was a reduction in the microbial proliferation, the removal of NA by the biochar-biofilm coalition increased to $87 \%$. An enhancement in metal sorption was also observed, indicating a synergistic removal in the co-existence of organic and inorganic contaminants. The results suggest a biochar-biofilm combined approach to treating cocontaminated industrial wastewater, though the removal mechanisms need to be further studied.

All in all, the selection of modification methods should base on the property and removal mechanism of the target contaminant. Generally, gas, steam, acid, and alkaline modifications increase the porosity of biochar, suitable for the contaminant whose sorption is dominant by pore-filling. Both acids and oxidants agents enrich the surface oxygen-containing groups of biochar with high cation exchangeability, which facilitates the sorption governed by ion exchange, such as heavy metal ions and $\mathrm{NH}_{4}^{+}$. The alkaline modification provides high aromaticity of the biochar, promoting the $\pi-\pi$ EDA interaction and sorption for some organic contaminants such as dyes and antibiotics. Notably, it also leads to a lower $\mathrm{O} / \mathrm{C}$ ratio, which 
714 strengthens the hydrophobic nature of biochar (Wang \& Wang, 2019), conducive to the sorption

715 of hydrophobic organic contaminants.

716

717 For negatively charged oxyanions such as $\mathrm{NO}_{3}{ }^{-}, \mathrm{PO}_{4}{ }^{3-}$, and $\mathrm{AsO}_{4}{ }^{3-}$, positively charged metal

718 oxides embedding into the biochar facilitates this type of sorption. Moreover, metal oxides

719 increase the active sites in biochar, which is related to the catalytic action of the composite

720 material. Incorporated nitrogen by amino-rich agents also acts as active sites and is linked with

721 such catalytic ability (Duan et al., 2018). Especially, transition metal salts increase the

722 magnetism of biochar to meet the separation needs; biochar combining with biofilm is applicable

723 for degradation of some toxic organic contaminants to reduce the toxicity.

724

725

\section{Environmental concerns and future directions}

726

Critically speaking, biochar is not yet widely applied and still in the test stage of researching. At

727

present, the production and application of biochar are not all-pervading, especially in some

728 developing countries where the complete industrial chains are lacking, because of the several

729 environmental concerns that cannot be ignored in the practical application of biochar. In this

730 case, arduous research work needs to be carried out to solve the potential environmental

731 problems and provide the developing countries with exercisable research directions to expand the

732 application of biochar. The potential environmental concerns and propositional future research

733 directions on proposed issues are briefly displayed in Figure 3.

734

735

Although feedstocks for biochar production are extensive and easy to get, these raw materials

736 need to be prepared (grinding, cleaning, and drying) and then pyrolyzed for the available

737 biochar. Modification steps are also required for an ideal sorption effect. Compared with

738 conventional activated carbon, these treatments for biochar will inevitably increase the production cost. Therefore, future researches should attempt to find a compromise between

740

741 optimizing the production process and maximizing the applicability of biochar to minimize the cost (Sizmur et al., 2017). Meanwhile, careful selections of feedstocks, production conditions,

742 and modification methods are critical to acquiring biochars with better performance. The

743 accumulation of a vast quantity of existing research results can help seek the best solutions. For

744 example, the micropore area of cellulose biochar $\left(280 \mathrm{~m}^{2} \cdot \mathrm{g}^{-1}\right)$ was larger than that of the lignin

745 biochar $\left(200 \mathrm{~m}^{2} \cdot \mathrm{g}^{-1}\right)$ when carbonized at the same temperature because of the resistance of

746 lignin, showing the cellulose biomass to be preferable than lignin biomass for biochar

747 production; the surface area and total pore volume of pinewood biochar pyrolyzed at higher temperature were much higher due of the more complete carbonization of lignin, implying that higher temperatures induce well-developed pore structure (Li et al., 2014).

750

751

752 The stability of biochar and biochar-based composites should be considered in the practical

753 application of biochar. Huang et al. (2019) found the possible dissolution of organic matters from biochar during the complexation with heavy metals, which may increase the carbon content in 
754 the water due to the high aromaticity and stability of organic matters. Moreover, the biochars, 755 especially those derived from sewage sludge, could contain high heavy metals that could leach 756 out during the application, causing additional heavy metals contamination (Wang \& Wang, 757 2019). For the biochar-based composites, there is a possibility that some of the embedded

758

759

760

761

762

763

764

765

766

767

768

769

770

771

772

773

774

775

776

777

778

779

780

781

782

783

784

785

786

787

788

789

790

791

792 materials would leach out from the biochar matrix if they are not well-fixed. Considering that the biochar stability generally refers to the stability of its carbon structure (Wang \& Wang, 2019), studies on the impacts of carbonization conditions on the carbon content and structure need to be conducted. For example, biochar produced via hydrothermal carbonization exhibits higher carbon content than that via gasification and pyrolysis (Funke \& Ziegler, 2010). Besides, constant water quality monitoring is strongly suggested during the life-cycle application process of the sorbents. Leaching or toxicity tests are proposed using water fleas, alga, fish, or luminous bacteria (Wang \& Wang, 2019) to determine whether toxic components are dissolving from the biochar.

So far, most researches have focused on the sorption of single contamination in aqueous solutions. However, the prevailing situation in real water application is the coexistence of a variety of contaminants, where synergistic and antagonistic sorption effects can be observed. The presence of multiple contaminants potentially results in ionic interference and competition of sorption sites, eventually reducing the removal efficiency. At present, empirical data based on sorption of co-contaminant is limited, appealing for the establishment of simultaneous sorption models, which could reveal the involved synergistic or antagonistic sorption mechanisms. To facilitate such studies, reports on biochar sorption should contain sufficient information about the sorbent properties and sorption conditions as detailed as possible in case of providing future directions. Several efforts have been reported, such as the simulated molecular equations for studying competitive sorption of co-contaminant (Bahamon et al., 2017); new analysis methods of meta-analysis (Wang et al., 2019) and in-depth analysis (Tran et al., 2019; Feng et al., 2016) have been carried out to develop possible new sorption models.

Although it is consensus that biochar is low-cost, renewable, and sustainable compared with activated carbon (Mohan et al., 2011), to achieve the sustainability it is necessary to seek solutions to recovery and desorption of the waste biochar, such as magnetization of biochar, which makes it accessible to separate the contaminant-loaded biochar from water by applying an external magnetic field. However, the desorption of waste biochar may cost a lot. On the other hand, if contaminants sorbed on biochar cannot be effectively desorbed and recovered, it is also feasible to use the waste biochar as a resource, which realizes the recycling of waste biochar in another way. For example, biochar laden with $\mathrm{N}$ and $\mathrm{P}$ can be of potential use as a slow-release fertilizer in agriculture or ecological remediation (Roy, 2017). Accordingly, biochar laden with $\mathrm{Cu}$ or $\mathrm{Zn}$ can be used as a micro-nutrient fertilizer as well. Nevertheless, attention should be paid whether any harmful components could release from the biochar, which could be sorbed by 
793 crops and consequently enter the food chain. Therefore, the safety of applying waste biochar into

794 soil requires further evaluation.

795

796

797

798

799

800

801

802

803

804

805

806

807

808

809

810

811

812

813

\section{Conclusions}

This review gives a systematical overview of the broad application of biochar in water and wastewater treatment to remove common and emerging organic and inorganic contaminants. The involved sorption mechanisms are demonstrated as a foundation of studies on biochar sorption behavior. Based on the mechanisms, attention has been paid on biochar modification to improve its performance, which aims to increase the surface area, porosity, or surface sorption sites of the biochar. Exciting frontiers of magnetic biochar and biochar-biofilm combination are also presented. Meanwhile, existing environmental concerns of biochar application are discussed in the aspects of cost, performance, stability, co-contaminant, and sustainability. Finally, future research directions are put forward to facilitate the practical application of biochar.

\section{Acknowledgments}

This work was supported by the National Science Fund for Distinguished Young Scholars of China (No. 51925803), the National Natural Science Foundation of China (No. 51878388), Shandong Provincial Key Research and Development Program (Major Scientific and Technological Innovation Project) (No. 2019JZZY010411), the Natural Science Foundation of Shandong Province (No. ZR2018QEE006), and Future Plan for Young Scholar of Shandong 814

\section{References}

816 Agegnehu, G., Srivastava, A.K., and Bird, M.I. 2017. The role of biochar and biochar-compost 817 in improving soil quality and crop performance: A review. APPLIED SOIL ECOLOGY 119:156818 170. https://doi.org/10.1016/j.apsoil.2017.06.008

819 Ahmad, M., Lee, S.S., Rajapaksha, A.U., Vithanage, M., Zhang, M., Cho, J.S., Lee, S., and Ok, 820 Y.S. 2013. Trichloroethylene adsorption by pine needle biochars produced at various pyrolysis 821 temperatures. BIORESOURCE TECHNOLOGY 143:615-622.

822 https://doi.org/10.1016/j.biortech.2013.06.033

823 Ahmad, M., Rajapaksha, A.U., Lim, J.E., Zhang, M., Bolan, N., Mohan, D., Vithanage, M., Lee, 824 S.S., and Ok, Y.S. 2014. Biochar as a sorbent for contaminant management in soil and water: A 825 review. CHEMOSPHERE 99:19-33. 10.1016/j.chemosphere.2013.10.071

826 Ahmed, M.B., Zhou, J.L., Ngo, H.H., Guo, W., and Chen, M. 2016. Progress in the preparation 827 and application of modified biochar for improved contaminant removal from water and 828 wastewater. BIORESOURCE TECHNOLOGY 214:836-851. 10.1016/j.biortech.2016.05.057

829 Ajmal, Z., Muhmood, A., Dong, R., and Wu, S. 2020. Probing the efficiency of magnetically 830 modified biomass-derived biochar for effective phosphate removal. JOURNAL OF

831 ENVIRONMENTAL MANAGEMENT 253:109730.

832 https://doi.org/10.1016/j.jenvman.2019.109730 
833 Awad, Y.M., Lee, S., Ahmed, M.B.M., Vu, N.T., Farooq, M., Kim, I.S., Kim, H.S., Vithanage,

834 M., Usman, A.R.A., Al-Wabel, M., Meers, E., Kwon, E.E., and Ok, Y.S. 2017. Biochar, a

835 potential hydroponic growth substrate, enhances the nutritional status and growth of leafy

836 vegetables. JOURNAL OF CLEANER PRODUCTION 156:581-588.

837 https://doi.org/10.1016/j.jclepro.2017.04.070

838 Bahamon, D., Carro, L., Guri, S., and Vega, L.F. 2017. Computational study of ibuprofen

839 removal from water by adsorption in realistic activated carbons. JOURNAL OF COLLOID AND

840 INTERFACE SCIENCE 498:323-334. 10.1016/j.jcis.2017.03.068

841 Bayabil, H.K., Stoof, C.R., Lehmann, J.C., Yitaferu, B., and Steenhuis, T.S. 2015. Assessing the

842 potential of biochar and charcoal to improve soil hydraulic properties in the humid Ethiopian

843 Highlands: The Anjeni watershed. GEODERMA 243-244:115-123.

844 10.1016/j.geoderma.2014.12.015

845 Bolton, L., Joseph, S., Greenway, M., Donne, S., Munroe, P., and Marjo, C.E. 2019. Phosphorus

846 adsorption onto an enriched biochar substrate in constructed wetlands treating wastewater.

847 Ecological Engineering: X 1:100005. https://doi.org/10.1016/j.ecoena.2019.100005

848 Boutsika, L., Karapanagioti, H., and Manariotis, I. 2014. Aqueous Mercury Sorption by Biochar 849 from Malt Spent Rootlets. Water, Air \& Soil Pollution 225:1.

850 Boutsika, L.G., Karapanagioti, H.K., and Manariotis, I.D. 2017. Effect of chloride and nitrate

851 salts on $\mathrm{Hg}(\mathrm{II})$ sorption by raw and pyrolyzed malt spent rootlets. Journal of Chemical

852 Technology \& Biotechnology 92:1912-1918. 10.1002/jctb.5215

853 Cao, X., Ma, L., Gao, B., and Harris, W. 2009. Dairy-Manure Derived Biochar Effectively Sorbs

854 Lead and Atrazine. ENVIRONMENTAL SCIENCE \& TECHNOLOGY 43:3285-3291.

855 10.1021/es803092k

856 Carvalho, I.T., and Santos, L. 2016. Antibiotics in the aquatic environments: A review of the

857 European scenario. ENVIRONMENT INTERNATIONAL 94:736-757.

858 https://doi.org/10.1016/j.envint.2016.06.025

859 Chaukura, N., Chiworeso, R., Gwenzi, W., Motsa, M.M., Munzeiwa, W., Moyo, W., Chikurunhe, 860 I., and Nkambule, T.T.I. 2020. A new generation low-cost biochar-clay composite 'biscuit'

861 ceramic filter for point-of-use water treatment. APPLIED CLAY SCIENCE 185.

862 https://doi.org/10.1016/j.clay.2019.105409

863 Chen, B., Zhou, D., and Zhu, L. 2008. Transitional Adsorption and Partition of Nonpolar and

864 Polar Aromatic Contaminants by Biochars of Pine Needles with Different Pyrolytic

865 Temperatures. ENVIRONMENTAL SCIENCE \& TECHNOLOGY 42:5137-5143.

866 10.1021/es8002684

867 Chen, B., and Chen, Z. 2009. Sorption of naphthalene and 1-naphthol by biochars of orange

868 peels with different pyrolytic temperatures. CHEMOSPHERE 76:127-133.

869 10.1016/j.chemosphere.2009.02.004

870 Chen, L., Chen, X.L., Zhou, C.H., Yang, H.M., Ji, S.F., Tong, D.S., Zhong, Z.K., Yu, W.H., and

871 Chu, M.Q. 2017. Environmental-friendly montmorillonite-biochar composites: Facile production

872 and tunable adsorption-release of ammonium and phosphate. JOURNAL OF CLEANER 
873 PRODUCTION 156:648-659. https://doi.org/10.1016/j.jclepro.2017.04.050

874 Chen, Y., Bai, S., Li, R., Su, G., Duan, X., Wang, S., Ren, N., and Ho, S. 2019. Magnetic

875 biochar catalysts from anaerobic digested sludge: Production, application and environment

876 impact. ENVIRONMENT INTERNATIONAL 126:302-308.

877 https://doi.org/10.1016/j.envint.2019.02.032

878 Chen, Y., Ho, S., Wang, D., Wei, Z., Chang, J., and Ren, N. 2018. Lead removal by a magnetic

879 biochar derived from persulfate-ZVI treated sludge together with one-pot pyrolysis.

880 BIORESOURCE TECHNOLOGY 247:463-470. https://doi.org/10.1016/j.biortech.2017.09.125

881 Chen, Z., Chen, B., and Chiou, C.T. 2012. Fast and Slow Rates of Naphthalene Sorption to

882 Biochars Produced at Different Temperatures. ENVIRONMENTAL SCIENCE \& TECHNOLOGY

883 46:11104-11111. 10.1021/es302345e

884 Dai, Y., Zhang, N., Xing, C., Cui, Q., and Sun, Q. 2019. The adsorption, regeneration and 885 engineering applications of biochar for removal organic pollutants: A review. CHEMOSPHERE

886 223:12-27. 10.1016/j.chemosphere.2019.01.161

887 Dalahmeh, S., Ahrens, L., Gros, M., Wiberg, K., and Pell, M. 2018. Potential of biochar filters

888 for onsite sewage treatment: Adsorption and biological degradation of pharmaceuticals in

889 laboratory filters with active, inactive and no biofilm. SCIENCE OF THE TOTAL

890 ENVIRONMENT 612:192-201. https://doi.org/10.1016/j.scitotenv.2017.08.178

891 Deng, C., Huang, L., Liang, Y., Xiang, H., Jiang, J., Wang, Q., Hou, J., and Chen, Y. 2019.

892 Response of microbes to biochar strengthen nitrogen removal in subsurface flow constructed

893 wetlands: Microbial community structure and metabolite characteristics. SCIENCE OF THE

894 TOTAL ENVIRONMENT 694:133687. https://doi.org/10.1016/j.scitotenv.2019.133687

895 Dos Reis, G.S.A.M., and Dias, S.L.P.P. 2016. Removal of phenolic compounds from aqueous

896 solutions using sludge-based activated carbons prepared by conventional heating and

897 microwave-assisted pyrolysis. Water Air Soil Pollut:33.

898 Duan, X., Sun, H., and Wang, S. 2018. Metal-Free Carbocatalysis in Advanced Oxidation

899 Reactions. ACCOUNTS OF CHEMICAL RESEARCH 51:678-687.

900 10.1021/acs.accounts.7b00535

901 Fan, R., Chen, C., Lin, J., Tzeng, J., Huang, C., Dong, C., and Huang, C.P. 2019. Adsorption

902 characteristics of ammonium ion onto hydrous biochars in dilute aqueous solutions.

903 BIORESOURCE TECHNOLOGY 272:465-472. https://doi.org/10.1016/j.biortech.2018.10.064

904 Feng, J., Hou, Y., Wang, X., Quan, W., Zhang, J., Wang, Y., and Li, L. 2016. In-depth study on

905 adsorption and photocatalytic performance of novel reduced graphene oxide-ZnFe2O4-

906 polyaniline composites. JOURNAL OF ALLOYS AND COMPOUNDS 681:157-166.

907 https://doi.org/10.1016/j.jallcom.2016.04.146

908 Frankel, M.L., Bhuiyan, T.I., Veksha, A., Demeter, M.A., Layzell, D.B., Helleur, R.J., Hill, J.M., 909 and Turner, R.J. 2016. Removal and biodegradation of naphthenic acids by biochar and attached

910 environmental biofilms in the presence of co-contaminating metals. BIORESOURCE

911 TECHNOLOGY 216:352-361. https://doi.org/10.1016/j.biortech.2016.05.084

912 Funke, A., and Ziegler, F. 2010. Hydrothermal carbonization of biomass: A summary and 
913 discussion of chemical mechanisms for process engineering. Biofuels, Bioproducts and

914 Biorefining 4:160-177. 10.1002/bbb.198

915 Gholami, L., Karimi, N., and Kavian, A. 2019. Soil and water conservation using biochar and

916 various soil moisture in laboratory conditions. CATENA 182:104151.

917 https://doi.org/10.1016/j.catena.2019.104151

918 Głąb, T., Żabiński, A., Sadowska, U., Gondek, K., Kopeć, M., Mierzwa-Hersztek, M., Tabor, S., 919 and Stanek-Tarkowska, J. 2020. Fertilization effects of compost produced from maize, sewage 920 sludge and biochar on soil water retention and chemical properties. Soil and Tillage Research 921 197:104493. https://doi.org/10.1016/j.still.2019.104493

922 Goswami, R., Shim, J., Deka, S., Kumari, D., Kataki, R., and Kumar, M. 2016. Characterization 923 of cadmium removal from aqueous solution by biochar produced from Ipomoea fistulosa at 924 different pyrolytic temperatures. ECOLOGICAL ENGINEERING 97:444-451.

925 10.1016/j.ecoleng.2016.10.007

926 Guo, S., Peng, J., Li, W., Yang, K., Zhang, L., Zhang, S., and Xia, H. 2009. Effects of $\mathrm{CO}_{2}$ 927 activation on porous structures of coconut shell-based activated carbons. APPLIED SURFACE 928 SCIENCE 255:8443-8449. 10.1016/j.apsusc.2009.05.150

929 Gupta, P., Prakash, D., and Srivastava, J. 2015. Determinants of immunization coverage in 930 Lucknow district. North American Journal of Medical Sciences 7:36. 10.4103/1947-

9312714.152076

932 Gwenzi, W., Chaukura, N., Noubactep, C., and Fnd, M. 2017. Biochar-based water treatment 933 systems as a potential low-cost and sustainable technology for clean water provision. JOURNAL 934 OF ENVIRONMENTAL MANAGEMENT:732-749.

935 Hadjittofi, L., Prodromou, M., and Pashalidis, I. 2014. Activated biochar derived from cactus 936 fibres - Preparation, characterization and application on $\mathrm{Cu}(\mathrm{II})$ removal from aqueous solutions. 937 BIORESOURCE TECHNOLOGY 159:460-464. 10.1016/j.biortech.2014.03.073

938 Hall-Stoodley, L., Costerton, J.W., and Stoodley, P. 2004. Bacterial biofilms: From the natural 939 environment to infectious diseases. NATURE REVIEWS MICROBIOLOGY:95-108.

$940 \quad 10.1038 /$ nrmicro821

941 Hamid, S., Chowdhury, Z., and Zain, S. 2014. Base Catalytic Approach: A Promising Technique 942 for the Activation of Biochar for Equilibrium Sorption Studies of Copper, Cu(II) Ions in Single 943 Solute System. Materials 7:2815-2832. 10.3390/ma7042815

944 Han, Y., Boateng, A.A., Qi, P.X., Lima, I.M., and Chang, J. 2013. Heavy metal and phenol 945 adsorptive properties of biochars from pyrolyzed switchgrass and woody biomass in correlation 946 with surface properties. JOURNAL OF ENVIRONMENTAL MANAGEMENT 118:196-204.

947 10.1016/j.jenvman.2013.01.001

948 Heo, J., Yoon, Y., Lee, G., Kim, Y., Han, J., and Park, C.M. 2019. Enhanced adsorption of 949 bisphenol A and sulfamethoxazole by a novel magnetic $\mathrm{CuZnFe} 2 \mathrm{O} 4$-biochar composite. 950 BIORESOURCE TECHNOLOGY 281:179-187. https://doi.org/10.1016/j.biortech.2019.02.091 951 Hu, X., Zhang, X., Ngo, H.H., Guo, W., Wen, H., Li, C., Zhang, Y., and Ma, C. 2020.

952 Comparison study on the ammonium adsorption of the biochars derived from different kinds of 
953 fruit peel. SCIENCE OF THE TOTAL ENVIRONMENT 707:135544.

954 10.1016/j.scitotenv.2019.135544

955 Huang, M., Li, Z., Luo, N., Yang, R., Wen, J., Huang, B., and Zeng, G. 2019. Application 956 potential of biochar in environment: Insight from degradation of biochar-derived DOM and 957 complexation of DOM with heavy metals. SCIENCE OF THE TOTAL ENVIRONMENT

958 646:220-228. https://doi.org/10.1016/j.scitotenv.2018.07.282

959 Huff, M.D., and Lee, J.W. 2016. Biochar-surface oxygenation with hydrogen peroxide.

960 JOURNAL OF ENVIRONMENTAL MANAGEMENT 165:17-21.

961 https://doi.org/10.1016/j.jenvman.2015.08.046

962 Inyang, M., Gao, B., Zimmerman, A., Zhang, M., and Chen, H. 2014. Synthesis, characterization, 963 and dye sorption ability of carbon nanotube-biochar nanocomposites. CHEMICAL

964 ENGINEERING JOURNAL 236:39-46. 10.1016/j.cej.2013.09.074

965 Jellali, S., Diamantopoulos, E., Haddad, K., Anane, M., Durner, W., and Mlayah, A. 2016. Lead

966 removal from aqueous solutions by raw sawdust and magnesium pretreated biochar:

967 Experimental investigations and numerical modelling. JOURNAL OF ENVIRONMENTAL

968 MANAGEMENT 180:439-449. https://doi.org/10.1016/j.jenvman.2016.05.055

969 Jin, H., Capareda, S., Chang, Z., Gao, J., Xu, Y., and Zhang, J. 2014. Biochar pyrolytically

970 produced from municipal solid wastes for aqueous $\mathrm{As}(\mathrm{V})$ removal: Adsorption property and its

971 improvement with KOH activation. BIORESOURCE TECHNOLOGY 169:622-629.

972 10.1016/j.biortech.2014.06.103

973 Jin, J., Kang, M., Sun, K., Pan, Z., Wu, F., and Xing, B. 2016. Properties of biochar-amended

974 soils and their sorption of imidacloprid, isoproturon, and atrazine. SCIENCE OF THE TOTAL

975 ENVIRONMENT 550:504-513. https://doi.org/10.1016/j.scitotenv.2016.01.117

976 Kaetzl, K., Lübken, M., Uzun, G., Gehring, T., Nettmann, E., Stenchly, K., and Wichern, M.

977 2019. On-farm wastewater treatment using biochar from local agroresidues reduces pathogens

978 from irrigation water for safer food production in developing countries. SCIENCE OF THE

979 TOTAL ENVIRONMENT 682:601-610. https://doi.org/10.1016/j.scitotenv.2019.05.142

980 Kangyi Lou, A.U.R.Y. 2016. Pyrolysis temperature and steam activation effects on sorption of

981 phosphate on pine sawdust biochars in aqueous solutions. Chemical Speciation \& Bioavailability

982 28:42-50.

983 Klasson, K.T., Ledbetter, C.A., Uchimiya, M., and Lima, I.M. 2013. Activated biochar removes $984100 \%$ dibromochloropropane from field well water. Environmental Chemistry Letters 11:271985 275. 10.1007/s10311-012-0398-7

986 Li, H., Dong, X., Da Silva, E.B., de Oliveira, L.M., Chen, Y., and Ma, L.Q. 2017. Mechanisms

987 of metal sorption by biochars: Biochar characteristics and modifications. CHEMOSPHERE

988 178:466-478. 10.1016/j.chemosphere.2017.03.072

989 Li, J., Hu, Z., Li, F., Fan, J., Zhang, J., Li, F., and Hu, H. 2019. Effect of oxygen supply strategy

990 on nitrogen removal of biochar-based vertical subsurface flow constructed wetland: Intermittent

991 aeration and tidal flow. CHEMOSPHERE 223:366-374.

992 https://doi.org/10.1016/j.chemosphere.2019.02.082 
993 Li, J., Li, Y., Wu, Y., and Zheng, M. 2014. A comparison of biochars from lignin, cellulose and 994 wood as the sorbent to an aromatic pollutant. JOURNAL OF HAZARDOUS MATERIALS

995 280:450-457. https://doi.org/10.1016/j.jhazmat.2014.08.033

996 Lima, I.M., and Marshall, W.E. 2005. Adsorption of selected environmentally important metals

997 by poultry manure-based granular activated carbons. Journal of Chemical Technology \&

998 Biotechnology 80:1054-1061. 10.1002/jctb.1283

999 Liu, H., Liang, S., Gao, J., Ngo, H.H., Guo, W., Guo, Z., and Li, Y. 2014. Development of

1000 biochars from pyrolysis of lotus stalks for $\mathrm{Ni}$ (II) sorption: Using zinc borate as flame retardant.

1001 JOURNAL OF ANALYTICAL AND APPLIED PYROLYSIS 107:336-341.

1002 10.1016/j.jaap.2014.02.018

1003 Lu, H., Zhang, W., Yang, Y., Huang, X., Wang, S., and Qiu, R. 2012. Relative distribution of

$1004 \mathrm{~Pb}^{2+}$ sorption mechanisms by sludge-derived biochar. WATER RESEARCH 46:854-862.

1005 10.1016/j.watres.2011.11.058

1006 Ma, Y., Liu, W., Zhang, N., Li, Y., Jiang, H., and Sheng, G. 2014. Polyethylenimine modified

1007 biochar adsorbent for hexavalent chromium removal from the aqueous solution. BIORESOURCE

1008 TECHNOLOGY 169:403-408. 10.1016/j.biortech.2014.07.014

1009 Manariotis, I.D., Fotopoulou, K.N., and Karapanagioti, H.K. 2015. Preparation and

1010 Characterization of Biochar Sorbents Produced from Malt Spent Rootlets. INDUSTRIAL \&

1011 ENGINEERING CHEMISTRY RESEARCH 54:9577-9584. DOI: 10.1021/acs.iecr.5b02698

1012 Manariotis, I.D., Karapanagioti, H.K., and Werner, D. 2017. In Focus: Novel Sorbents for

1013 Environmental Remediation. JOURNAL OF CHEMICAL TECHNOLOGY AND

1014 BIOTECHNOLOGY 92:1861.

1015 Meyer, S., Glaser, B., and Quicker, P. 2011. Technical, Economical, and Climate-Related

1016 Aspects of Biochar Production Technologies: A Literature Review. ENVIRONMENTAL

1017 SCIENCE \& TECHNOLOGY 45:9473-9483. 10.1021/es201792c

1018 Mohan, D., Kumar, H., Sarswat, A., Alexandre-Franco, M., and Pittman, C.U. 2014. Cadmium

1019 and lead remediation using magnetic oak wood and oak bark fast pyrolysis bio-chars.

1020 CHEMICAL ENGINEERING JOURNAL 236:513-528. 10.1016/j.cej.2013.09.057

1021 Mohan, D., Sharma, R., Singh, V.K., Steele, P., and Pittman, C.U. 2011. Fluoride Removal from

1022 Water using Bio-Char, a Green Waste, Low-Cost Adsorbent: Equilibrium Uptake and Sorption

1023 Dynamics Modeling. INDUSTRIAL \& ENGINEERING CHEMISTRY RESEARCH 51:900-914.

1024 10.1021/ie202189v

1025 Mohanty, S.K., Cantrell, K.B., Nelson, K.L., and Boehm, A.B. 2014. Efficacy of biochar to

1026 remove Escherichia coli from stormwater under steady and intermittent flow. WATER

1027 RESEARCH 61:288-296. https://doi.org/10.1016/j.watres.2014.05.026

1028 Moreira, M.T., Noya, I., and Feijoo, G. 2017. The prospective use of biochar as adsorption

1029 matrix - A review from a lifecycle perspective. BIORESOURCE TECHNOLOGY 246:135-141.

1030 10.1016/j.biortech.2017.08.041

1031 Nachenius, R.W., Ronsse, F., Venderbosch, R.H., and Prins, W. 2013. Biomass Pyrolysis. In:

1032 Murzin, D.Y., ed. Advances in Chemical Engineering. Academic Press, 75-139.

Peer] reviewing PDF | (2019:11:42777:1:1:NEW 9 Mar 2020) 
1033 Nanda, S., Dalai, A.K., Gökalp, I., and Kozinski, J.A. 2016. Valorization of horse manure 1034 through catalytic supercritical water gasification. WASTE MANAGEMENT 52:147-158.

1035 https://doi.org/10.1016/j.wasman.2016.03.049

1036 Oliveira, F.R., Patel, A.K., Jaisi, D.P., Adhikari, S., Lu, H., and Khanal, S.K. 2017.

1037 Environmental application of biochar: Current status and perspectives. BIORESOURCE

1038 TECHNOLOGY 246:110-122. 10.1016/j.biortech.2017.08.122

1039 ÖZ, H. 2018. A new approach to soil solarization: Addition of biochar to the effect of soil

1040 temperature and quality and yield parameters of lettuce (Lactuca Sativa L. Duna). SCIENTIA

1041 HORTICULTURAE 228:153-161. https://doi.org/10.1016/j.scienta.2017.10.021

1042 Pan, J., Jiang, J., and Xu, R. 2013. Adsorption of Cr(III) from acidic solutions by crop straw

1043 derived biochars. JOURNAL OF ENVIRONMENTAL SCIENCES 25:1957-1965.

1044 https://doi.org/10.1016/S1001-0742(12)60305-2

1045 Peiris, C., Gunatilake, S.R., Mlsna, T.E., Mohan, D., and Vithanage, M. 2017. Biochar based

1046 removal of antibiotic sulfonamides and tetracyclines in aquatic environments: A critical review.

1047 BIORESOURCE TECHNOLOGY 246:150-159. 10.1016/j.biortech.2017.07.150

1048 Perez-Mercado, L.F., Lalander, C., Joel, A., Ottoson, J., Dalahmeh, S., and Vinnerås, B. 2019.

1049 Biochar filters as an on-farm treatment to reduce pathogens when irrigating with wastewater-

1050 polluted sources. JOURNAL OF ENVIRONMENTAL MANAGEMENT 248:109295.

1051 https://doi.org/10.1016/j.jenvman.2019.109295

1052 Petrović, J.T., Stojanović, M.D., Milojković, J.V., Petrović, M.S., Šoštarić, T.D., Laušević, M.D., 1053 and Mihajlović, M.L. 2016. Alkali modified hydrochar of grape pomace as a perspective 1054 adsorbent of $\mathrm{Pb}^{2+}$ from aqueous solution. JOURNAL OF ENVIRONMENTAL MANAGEMENT

1055 182:292-300. 10.1016/j.jenvman.2016.07.081

1056 Pietrzak, R., Nowicki, P., Kaźmierczak, J., Kuszyńska, I., Goscianska, J., and Przepiórski, J.

1057 2014. Comparison of the effects of different chemical activation methods on properties of

1058 carbonaceous adsorbents obtained from cherry stones. Chemical Engineering Research and

1059 Design 92:1187-1191. https://doi.org/10.1016/j.cherd.2013.10.005

1060 Pradhananga, R., Adhikari, L., Shrestha, R., Adhikari, M., Rajbhandari, R., Ariga, K., and

1061 Shrestha, L. 2017. Wool Carpet Dye Adsorption on Nanoporous Carbon Materials Derived from

1062 Agro-Product. C 3:12. 10.3390/c3020012

1063 Qian, K., Kumar, A., Patil, K., Bellmer, D., Wang, D., Yuan, W., and Huhnke, R. 2013. Effects

1064 of Biomass Feedstocks and Gasification Conditions on the Physiochemical Properties of Char.

1065 Energies 6:3972-3986. 10.3390/en6083972

1066 Qian, K., Kumar, A., Zhang, H., Bellmer, D., and Huhnke, R. 2015. Recent advances in

1067 utilization of biochar. Renewable and Sustainable Energy Reviews 42:1055-1064.

1068 https://doi.org/10.1016/j.rser.2014.10.074

1069 Qiu, Y., Zheng, Z., Zhou, Z., and Sheng, G.D. 2009. Effectiveness and mechanisms of dye

1070 adsorption on a straw-based biochar. BIORESOURCE TECHNOLOGY 100:5348-5351.

1071 10.1016/j.biortech.2009.05.054

1072 Rajapaksha, A.U., Chen, S.S., Tsang, D.C.W., Zhang, M., Vithanage, M., Mandal, S., Gao, B., 
1073 Bolan, N.S., and Ok, Y.S. 2016. Engineered/designer biochar for contaminant

1074 removal/immobilization from soil and water: Potential and implication of biochar modification.

1075 CHEMOSPHERE 148:276-291. 10.1016/j.chemosphere.2016.01.043

1076 Rao, N.S., and Mathew, K.P. 1995. Effects of exchangeable cations on hydraulic conductivity of 1077 a marine clay. CLAYS AND CLAY MINERALS:433-437.

1078 Razzaghi, F., Obour, P.B., and Arthur, E. 2020. Does biochar improve soil water retention? A 1079 systematic review and meta-analysis. GEODERMA 361:114055.

1080 https://doi.org/10.1016/j.geoderma.2019.114055

1081 Ren, J., Li, N., Li, L., An, J., Zhao, L., and Ren, N. 2015. Granulation and ferric oxides loading

1082 enable biochar derived from cotton stalk to remove phosphate from water. BIORESOURCE

1083 TECHNOLOGY 178:119-125. https://doi.org/10.1016/j.biortech.2014.09.071

1084 Roy, E.D. 2017. Phosphorus recovery and recycling with ecological engineering: A review.

1085 ECOLOGICAL ENGINEERING 98:213-227. 10.1016/j.ecoleng.2016.10.076

1086 S, R., and P, B. 2019. The potential of lignocellulosic biomass precursors for biochar production:

1087 Performance, mechanism and wastewater application - A review. INDUSTRIAL CROPS AND

1088 PRODUCTS 128:405-423. 10.1016/j.indcrop.2018.11.041

1089 Sanroman, M.A., Lee, D.J., Khanal, S., and Ok, Y.S. 2017a. Special Issue on Biochar:

1090 Production, Characterization and Applications - Beyond Soil Applications. BIORESOURCE

1091 TECHNOLOGY 246:1. 10.1016/j.biortech.2017.10.006

1092 Sanroman, M.A., Lee, D.J., Khanal, S., and Ok, Y.S. 2017b. Special Issue on Biochar:

1093 Production, Characterization and Applications - Beyond Soil Applications. BIORESOURCE

1094 TECHNOLOGY 246:1. https://doi.org/10.1016/j.biortech.2017.10.006

1095 Shang, M., Liu, Y., Liu, S., Zeng, G., Tan, X., Jiang, L., Huang, X., Ding, Y., Guo, Y., and

1096 Wang, S. 2016. A novel graphene oxide coated biochar composite: Synthesis, characterization

1097 and application for $\mathrm{Cr}(\mathrm{VI})$ removal. RSC Advances 6:85202-85212. DOI: 10.1039/c6ra07151a

1098 Shao, B., Dong, D., Wu, Y., Hu, J., Meng, J., Tu, X., and Xu, S. 2005. Simultaneous

1099 determination of 17 sulfonamide residues in porcine meat, kidney and liver by solid-phase

1100 extraction and liquid chromatography-tandem mass spectrometry. ANALYTICA CHIMICA ACTA

1101 546:174-181. https://doi.org/10.1016/j.aca.2005.05.007

1102 Shi, Y., Shan, R., Lu, L., Yuan, H., Jiang, H., Zhang, Y., and Chen, Y. 2020. High-efficiency

1103 removal of $\mathrm{Cr}(\mathrm{VI})$ by modified biochar derived from glue residue. JOURNAL OF CLEANER

1104 PRODUCTION 254:119935. https://doi.org/10.1016/j.jclepro.2019.119935

1105 Shim, T., Yoo, J., Ryu, C., Park, Y., and Jung, J. 2015. Effect of steam activation of biochar

1106 produced from a giant Miscanthus on copper sorption and toxicity. BIORESOURCE

1107 TECHNOLOGY 197:85-90. 10.1016/j.biortech.2015.08.055

1108 Singh, R., Paul, D., and Jain, R.K. 2006. Biofilms: Implications in bioremediation. TRENDS IN

1109 MICROBIOLOGY 14:389-397. 10.1016/j.tim.2006.07.001

1110 Sizmur, T., Fresno, T., Akgül, G., Frost, H., and Moreno-Jiménez, E. 2017. Biochar modification

1111 to enhance sorption of inorganics from water. BIORESOURCE TECHNOLOGY 246:34-47.

1112 10.1016/j.biortech.2017.07.082 
1113 Sohi, S.P. 2012. Carbon Storage with Benefits. SCIENCE 338(6110):1034-1035.

1114 Soinne, H., Hovi, J., Tammeorg, P., and Turtola, E. 2014. Effect of biochar on phosphorus

1115 sorption and clay soil aggregate stability. GEODERMA 219-220:162-167.

1116 https://doi.org/10.1016/j.geoderma.2013.12.022

1117 Song, Z., Lian, F., Yu, Z., Zhu, L., Xing, B., and Qiu, W. 2014. Synthesis and characterization of 1118 a novel MnOx-loaded biochar and its adsorption properties for $\mathrm{Cu} 2+$ in aqueous solution.

1119 CHEMICAL ENGINEERING JOURNAL 242:36-42. 10.1016/j.cej.2013.12.061

1120 Sun, K., Kang, M., Zhang, Z., Jin, J., Wang, Z., Pan, Z., Xu, D., Wu, F., and Xing, B. 2013.

1121 Impact of Deashing Treatment on Biochar Structural Properties and Potential Sorption

1122 Mechanisms of Phenanthrene. ENVIRONMENTAL SCIENCE \& TECHNOLOGY 47:11473-

1123 11481. 10.1021/es4026744

1124 Tan, X., Liu, Y., Zeng, G., Wang, X., Hu, X., Gu, Y., and Yang, Z. 2015. Application of biochar 1125 for the removal of pollutants from aqueous solutions. CHEMOSPHERE 125:70-85.

1126 10.1016/j.chemosphere.2014.12.058

1127 Tang, J., Lv, H., Gong, Y., and Huang, Y. 2015. Preparation and characterization of a novel

1128

1129 graphene/biochar composite for aqueous phenanthrene and mercury removal. BIORESOURCE

1130 TECHNOLOGY 196:355-363. https://doi.org/10.1016/j.biortech.2015.07.047

1131 Tanure, M.M.C., Da Costa, L.M., Huiz, H.A., Fernandes, R.B.A., Cecon, P.R., Pereira Junior,

1132 J.D., and Da Luz, J.M.R. 2019. Soil water retention, physiological characteristics, and growth of

1133 maize plants in response to biochar application to soil. Soil and Tillage Research 192:164-173.

1134 https://doi.org/10.1016/j.still.2019.05.007

1135 Tchomgui-Kamga, E., Alonzo, V., Nanseu-Njiki, C.P., Audebrand, N., Ngameni, E., and

1136 Darchen, A. 2010. Preparation and characterization of charcoals that contain dispersed aluminum oxide as adsorbents for removal of fluoride from drinking water. CARBON 48:333-343.

1138 https://doi.org/10.1016/j.carbon.2009.09.034

1139 Thornley, P., Upham, P., and Tomei, J. 2009. Sustainability constraints on UK bioenergy development. ENERGY POLICY 37:5623-5635. https://doi.org/10.1016/j.enpol.2009.08.028 Trakal, L., Bingöl, D., Pohořelý, M., Hruška, M., and Komárek, M. 2014. Geochemical and spectroscopic investigations of $\mathrm{Cd}$ and $\mathrm{Pb}$ sorption mechanisms on contrasting biochars:

1143 Engineering implications. BIORESOURCE TECHNOLOGY 171:442-451.

1144 https://doi.org/10.1016/j.biortech.2014.08.108 Tran, H.N., Nguyen, D.T., Le, G.T., Tomul, F., Lima, E.C., Woo, S.H., Sarmah, A.K., Nguyen, 1146 H.Q., Nguyen, P.T., Nguyen, D.D., Nguyen, T.V., Vigneswaran, S., Vo, D.N., and Chao, H. 2019. Adsorption mechanism of hexavalent chromium onto layered double hydroxides-based adsorbents: A systematic in-depth review. JOURNAL OF HAZARDOUS MATERIALS 373:258270. https://doi.org/10.1016/j.jhazmat.2019.03.018

Uchimiya, M., Ohno, T., and He, Z. 2013. Pyrolysis temperature-dependent release of dissolved organic carbon from plant, manure, and biorefinery wastes. JOURNAL OF ANALYTICAL AND 
1153 Deisopropylatrazine on Broiler Litter Biochars. JOURNAL OF AGRICULTURAL AND FOOD

1154 CHEMISTRY 58:12350-12356. 10.1021/jf102152q

1155 Valili, S., Siavalas, G., Karapanagioti, H.K., Manariotis, I.D., and Christanis, K. 2013.

1156 Phenanthrene removal from aqueous solutions using well-characterized, raw, chemically treated, 1157 and charred malt spent rootlets, a food industry by-product. JOURNAL OF ENVIRONMENTAL

1158 MANAGEMENT 128:252-258. https://doi.org/10.1016/j.jenvman.2013.04.057

1159 Viglašová, E., Galamboš, M., Danková, Z., Krivosudský, L., Lengauer, C.L., Hood-Nowotny, R., 1160 Soja, G., Rompel, A., Matík, M., and Briančin, J. 2018. Production, characterization and 1161 adsorption studies of bamboo-based biochar/montmorillonite composite for nitrate removal.

1162 WASTE MANAGEMENT 79:385-394. https://doi.org/10.1016/j.wasman.2018.08.005

1163 Wang, J., and Wang, S. 2019. Preparation, modification and environmental application of

1164 biochar: A review. JOURNAL OF CLEANER PRODUCTION 227:1002-1022.

1165 10.1016/j.jclepro.2019.04.282

1166 Wang, S., Gao, B., Zimmerman, A.R., Li, Y., Ma, L., Harris, W.G., and Migliaccio, K.W. 2015.

1167 Removal of arsenic by magnetic biochar prepared from pinewood and natural hematite.

1168 BIORESOURCE TECHNOLOGY 175:391-395. https://doi.org/10.1016/j.biortech.2014.10.104

1169 Wang, Y., Villamil, M.B., Davidson, P.C., and Akdeniz, N. 2019. A quantitative understanding 1170 of the role of co-composted biochar in plant growth using meta-analysis. SCIENCE OF THE

1171 TOTAL ENVIRONMENT 685:741-752. https://doi.org/10.1016/j.scitotenv.2019.06.244

1172 Windeatt, J.H., Ross, A.B., Williams, P.T., Forster, P.M., Nahil, M.A., and Singh, S. 2014.

1173 Characteristics of biochars from crop residues: Potential for carbon sequestration and soil

1174 amendment. JOURNAL OF ENVIRONMENTAL MANAGEMENT 146:189-197.

1175 https://doi.org/10.1016/j.jenvman.2014.08.003

1176 Wu, X., Zhang, Y., Dou, X., and Yang, M. 2007. Fluoride removal performance of a novel Fe-

1177 Al-Ce trimetal oxide adsorbent. CHEMOSPHERE 69:1758-1764.

1178 https://doi.org/10.1016/j.chemosphere.2007.05.075

1179 Xie, M., Chen, W., Xu, Z., Zheng, S., and Zhu, D. 2014. Adsorption of sulfonamides to

1180 demineralized pine wood biochars prepared under different thermochemical conditions.

1181 ENVIRONMENTAL POLLUTION 186:187-194. 10.1016/j.envpol.2013.11.022

1182 Xu, R., Xiao, S., Yuan, J., and Zhao, A. 2011. Adsorption of methyl violet from aqueous

1183 solutions by the biochars derived from crop residues. BIORESOURCE TECHNOLOGY

1184 102:10293-10298. 10.1016/j.biortech.2011.08.089

1185 Xu, X., Cao, X., Zhao, L., Wang, H., Yu, H., and Gao, B. 2013. Removal of Cu, Zn, and Cd

1186 from aqueous solutions by the dairy manure-derived biochar. ENVIRONMENTAL SCIENCE

1187 AND POLLUTION RESEARCH 20:358-368. 10.1007/s11356-012-0873-5

$1188 \mathrm{Xu}, \mathrm{X}$., Cao, X., and Zhao, L. 2013. Comparison of rice husk- and dairy manure-derived

1189 biochars for simultaneously removing heavy metals from aqueous solutions: Role of mineral

1190 components in biochars. CHEMOSPHERE 92:955-961. 10.1016/j.chemosphere.2013.03.009

1191 Xu, X., Schierz, A., Xu, N., and Cao, X. 2016. Comparison of the characteristics and

1192 mechanisms of $\mathrm{Hg}(\mathrm{II})$ sorption by biochars and activated carbon. JOURNAL OF COLLOID AND

Peer] reviewing PDF | (2019:11:42777:1:1:NEW 9 Mar 2020) 
1193 INTERFACE SCIENCE 463:55-60. https://doi.org/10.1016/j.jcis.2015.10.003

1194 Yang, G., and Jiang, H. 2014. Amino modification of biochar for enhanced adsorption of copper 1195 ions from synthetic wastewater. WATER RESEARCH 48:396-405. 10.1016/j.watres.2013.09.050 1196 Yang, Q., Wang, X., Luo, W., Sun, J., Xu, Q., Chen, F., Zhao, J., Wang, S., Yao, F., Wang, D., 1197 Li, X., and Zeng, G. 2018. Effectiveness and mechanisms of phosphate adsorption on iron1198 modified biochars derived from waste activated sludge. BIORESOURCE TECHNOLOGY 1199 247:537-544. https://doi.org/10.1016/j.biortech.2017.09.136

1200 Yao, Y., Gao, B., Chen, H., Jiang, L., Inyang, M., Zimmerman, A.R., Cao, X., Yang, L., Xue, Y., 1201 and Li, H. 2012. Adsorption of sulfamethoxazole on biochar and its impact on reclaimed water 1202 irrigation. JOURNAL OF HAZARDOUS MATERIALS 209-210:408-413.

1203 10.1016/j.jhazmat.2012.01.046

1204 Yao, Y., Gao, B., Fang, J., Zhang, M., Chen, H., Zhou, Y., Creamer, A.E., Sun, Y., and Yang, L. 1205 2014. Characterization and environmental applications of clay-biochar composites. CHEMICAL 1206 ENGINEERING JOURNAL 242:136-143. https://doi.org/10.1016/j.cej.2013.12.062

1207 Yi, Y., Huang, Z., Lu, B., Xian, J., Tsang, E.P., Cheng, W., Fang, J., and Fang, Z. 2020. 1208 Magnetic biochar for environmental remediation: A review. BIORESOURCE TECHNOLOGY 1209 298:122468. https://doi.org/10.1016/j.biortech.2019.122468

1210 Yin, Q., Liu, M., and Ren, H. 2019. Biochar produced from the co-pyrolysis of sewage sludge 1211 and walnut shell for ammonium and phosphate adsorption from water. JOURNAL OF 1212 ENVIRONMENTAL MANAGEMENT 249:109410.

1213 https://doi.org/10.1016/j.jenvman.2019.109410

1214 Yin, Q., Zhang, B., Wang, R., and Zhao, Z. 2017. Biochar as an adsorbent for inorganic nitrogen 1215 and phosphorus removal from water: A review. ENVIRONMENTAL SCIENCE AND 1216 POLLUTION RESEARCH 24:26297-26309. 10.1007/s11356-017-0338-y

1217 Ying, G., Xing, Y., Li, Z., Pan, J., and Kuang, X. 2010. Advantages of Psychrophiles in 1218 Improving Bio-Treatment Efficiency of Small Size Constructed Wetlands During Cold Weather. 1219 Environmental Progress \& Sustainable Energy 29:25-33. 10.1002/ep

1220 Yu, F., Li, Y., Han, S., and Ma, J. 2016. Adsorptive removal of antibiotics from aqueous solution 1221 using carbon materials. CHEMOSPHERE 153:365-385.

1222 https://doi.org/10.1016/j.chemosphere.2016.03.083

1223 Yu, H., Zou, W., Chen, J., Chen, H., Yu, Z., Huang, J., Tang, H., Wei, X., and Gao, B. 2019.

1224 Biochar amendment improves crop production in problem soils: A review. JOURNAL OF 1225 ENVIRONMENTAL MANAGEMENT 232:8-21. https://doi.org/10.1016/j.jenvman.2018.10.117 1226 Yu, J., Wang, L., Chi, R., Zhang, Y., Xu, Z., and Guo, J. 2013. Competitive adsorption of Pb2+ 1227 and $\mathrm{Cd} 2+$ on magnetic modified sugarcane bagasse prepared by two simple steps. APPLIED 1228 SURFACE SCIENCE 268:163-170. https://doi.org/10.1016/j.apsusc.2012.12.047

1229 Zazycki, M.A., Godinho, M., Perondi, D., Foletto, E.L., Collazzo, G.C., and Dotto, G.L. 2018. 1230 New biochar from pecan nutshells as an alternative adsorbent for removing reactive red 141 from 1231 aqueous solutions. JOURNAL OF CLEANER PRODUCTION 171:57-65.

1232 https://doi.org/10.1016/j.jclepro.2017.10.007 
1233 Zhang, F., Wang, X., Yin, D., Peng, B., Tan, C., Liu, Y., Tan, X., and Wu, S. 2015. Efficiency

1234

1235

1236

1237

1238

1239

1240

1241

1242

1243

1244

1245

1246

1247

1248

1249

1250

1251

1252

1253

1254

1255

1256

1257

1258

1259

1260

1261

1262

1263

1264

1265

1266

1267

1268

1269

1270

1271

1272

and mechanisms of $\mathrm{Cd}$ removal from aqueous solution by biochar derived from water hyacinth (Eichornia crassipes). JOURNAL OF ENVIRONMENTAL MANAGEMENT 153:68-73.

https://doi.org/10.1016/j.jenvman.2015.01.043

Zhang, M., Gao, B., Yao, Y., Xue, Y., and Inyang, M. 2012. Synthesis of porous MgO-biochar nanocomposites for removal of phosphate and nitrate from aqueous solutions. CHEMICAL ENGINEERING JOURNAL 210:26-32. 10.1016/j.cej.2012.08.052

Zhang, M., Gao, B., Yao, Y., and Inyang, M. 2013. Phosphate removal ability of biochar/MgAlLDH ultra-fine composites prepared by liquid-phase deposition. CHEMOSPHERE 92:1042-1047. 10.1016/j.chemosphere.2013.02.050

Zhang, P., Sun, H., Min, L., and Ren, C. 2018. Biochars change the sorption and degradation of thiacloprid in soil: Insights into chemical and biological mechanisms. ENVIRONMENTAL POLLUTION 236:158-167. https://doi.org/10.1016/j.envpol.2018.01.030

Zhang, S., Ji, Y., Dang, J., Zhao, J., and Chen, S. 2019. Magnetic apple pomace biochar: Simple preparation, characterization, and application for enriching $\mathrm{Ag}(\mathrm{I})$ in effluents. SCIENCE OF THE TOTAL ENVIRONMENT 668:115-123. https://doi.org/10.1016/j.scitotenv.2019.02.318 ZHANG, T., WALAWENDER, W., FAN, L., FAN, M., DAUGAARD, D., and BROWN, R. 2004. Preparation of activated carbon from forest and agricultural residues through $\mathrm{CO}$ activation. CHEMICAL ENGINEERING JOURNAL 105:53-59. 10.1016/j.cej.2004.06.011 Zhao, J., Liang, G., Zhang, X., Cai, X., Li, R., Xie, X., and Wang, Z. 2019. Coating magnetic biochar with humic acid for high efficient removal of fluoroquinolone antibiotics in water. SCIENCE OF THE TOTAL ENVIRONMENT 688:1205-1215.

https://doi.org/10.1016/j.scitotenv.2019.06.287

Zhao, L., Zheng, W., Mašek, O., Chen, X., Gu, B., Sharma, B.K., and Cao, X. 2017. Roles of Phosphoric Acid in Biochar Formation: Synchronously Improving Carbon Retention and Sorption Capacity. Journal of Environment Quality 46:393. 10.2134/jeq2016.09.0344

Zheng, W., Guo, M., Chow, T., Bennett, D.N., and Rajagopalan, N. 2010. Sorption properties of greenwaste biochar for two triazine pesticides. JOURNAL OF HAZARDOUS MATERIALS 181:121-126. 10.1016/j.jhazmat.2010.04.103

Zhong, D., Zhang, Y., Wang, L., Chen, J., Jiang, Y., Tsang, D.C.W., Zhao, Z., Ren, S., Liu, Z., and Crittenden, J.C. 2018. Mechanistic insights into adsorption and reduction of hexavalent chromium from water using magnetic biochar composite: Key roles of $\mathrm{Fe} 3 \mathrm{O} 4$ and persistent free radicals. ENVIRONMENTAL POLLUTION 243:1302-1309.

https://doi.org/10.1016/j.envpol.2018.08.093

Zhong, J.K.L.L. 2018. Advances on the research of the effect of biochar on the environmental behavior of antibiotics. J. Saf. Environ. 18:657-663.

Zhou, X., Liang, C., Jia, L., Feng, L., Wang, R., and Wu, H. 2018. An innovative biocharamended substrate vertical flow constructed wetland for low $\mathrm{C} / \mathrm{N}$ wastewater treatment: Impact of influent strengths. BIORESOURCE TECHNOLOGY 247:844-850.

10.1016/j.biortech.2017.09.044

PeerJ reviewing PDF | (2019:11:42777:1:1:NEW 9 Mar 2020) 
1273 Zhou, Y., Gao, B., Zimmerman, A.R., Chen, H., Zhang, M., and Cao, X. 2014. Biochar1274 supported zerovalent iron for removal of various contaminants from aqueous solutions. 1275 BIORESOURCE TECHNOLOGY 152:538-542. 10.1016/j.biortech.2013.11.021

1276 Zhou, Y., Gao, B., Zimmerman, A.R., Fang, J., Sun, Y., and Cao, X. 2013. Sorption of heavy 1277 metals on chitosan-modified biochars and its biological effects. CHEMICAL ENGINEERING 1278 JOURNAL 231:512-518. 10.1016/j.cej.2013.07.036

1279 Zhou, Y., Liu, X., Xiang, Y., Wang, P., Zhang, J., Zhang, F., Wei, J., Luo, L., Lei, M., and Tang, 1280 L. 2017. Modification of biochar derived from sawdust and its application in removal of 1281 tetracycline and copper from aqueous solution: Adsorption mechanism and modelling. 1282 BIORESOURCE TECHNOLOGY 245:266-273. https://doi.org/10.1016/j.biortech.2017.08.178 1283 Zhu, X., Liu, Y., Zhou, C., Luo, G., Zhang, S., and Chen, J. 2014. A novel porous carbon derived 1284 from hydrothermal carbon for efficient adsorption of tetracycline. CARBON 77:627-636.

1285 10.1016/j.carbon.2014.05.067

1286 


\section{Table 1 (on next page)}

Removal of various contaminants from water and wastewater by biochar derived from different feedstocks. 


\section{$1 \quad$ Table 1}

2 Removal of various contaminants from water and wastewater by biochar derived from different feedstocks.

\begin{tabular}{|c|c|c|c|c|c|}
\hline & Biomass feedstock & Production method & Target contaminant & Maximum removal ability & Reference \\
\hline \multirow{5}{*}{ Heavy metals } & $\begin{array}{l}\text { Bamboo, bagasse, } \\
\text { hickory wood, } \\
\text { peanut hull }\end{array}$ & $\begin{array}{l}\text { Pyrolysis at } 600^{\circ} \mathrm{C} \text { then } \\
\text { chitosan modification }\end{array}$ & $\mathrm{Cd}^{2+}, \mathrm{Pb}^{2+}, \mathrm{Cu}^{2+}$ & $14.3 \mathrm{mg} \cdot \mathrm{g}^{-1}$ for $\mathrm{Pb}^{2+}$ & $\begin{array}{l}\text { (Zhou et al., } \\
\text { 2013) }\end{array}$ \\
\hline & Malt spent rootlets & Pyrolysis at $850^{\circ} \mathrm{C}$ for $1 \mathrm{~h}$ & $\operatorname{Hg}(\mathrm{II})$ & $103 \mathrm{mg} \cdot \mathrm{g}^{-1}$ & $\begin{array}{l}\text { (Boutsika et } \\
\text { al., 2014) }\end{array}$ \\
\hline & Malt spent rootlets & Pyrolysis at $300-900^{\circ} \mathrm{C}$ & $\operatorname{Hg}(\mathrm{II})$ & $130 \mathrm{mg} \cdot \mathrm{g}^{-1}$ for MSR750 & $\begin{array}{l}\text { (Manariotis } \\
\text { et al., 2015) }\end{array}$ \\
\hline & Waste glue residue & $\mathrm{ZnCl}_{2}$ modification & $\mathrm{Cr}(\mathrm{VI})$ & $325.5 \mathrm{mg} \cdot \mathrm{g}^{-1}$ & $\begin{array}{l}\text { (Shi et al., } \\
\text { 2020) }\end{array}$ \\
\hline & Lotus stalks & $\begin{array}{l}\text { Zinc borate as flame retardant, } \\
\text { pyrolysis at } 300,350 \text {, and } \\
400^{\circ} \mathrm{C}\end{array}$ & $\mathrm{Ni}(\mathrm{II})$ & $\begin{array}{l}61.7 \mathrm{mg} \cdot \mathrm{g}^{-1} \text { for } 0.5 \mathrm{~g} \\
\mathrm{ZB} / \mathrm{g} \mathrm{LS} \text { pyrolysis at } \\
300^{\circ} \mathrm{C}\end{array}$ & $\begin{array}{l}\text { (Liu et al., } \\
\text { 2014) }\end{array}$ \\
\hline \multirow[t]{2}{*}{ Dyes } & Bamboo cane & $\begin{array}{l}\text { Phosphoric acid modification } \\
\text { then pyrolysis at } 400,500 \text {, and } \\
600^{\circ} \mathrm{C}\end{array}$ & $\begin{array}{l}\text { Lanasyn Orange and } \\
\text { Lanasyn Gray }\end{array}$ & $\begin{array}{l}2.6 \times 10^{3} \mathrm{mg} \cdot \mathrm{g}^{-1} \text { for both } \\
\text { dyes }\end{array}$ & $\begin{array}{l}\text { (Pradhananga } \\
\text { et al., 2017) }\end{array}$ \\
\hline & Pecan nutshell & Pyrolysis at $800^{\circ} \mathrm{C}$ for $1 \mathrm{~h}$ & Reactive Red 141 & $130 \mathrm{mg} \cdot \mathrm{g}^{-1}$ & $\begin{array}{l}\text { (Zazycki et } \\
\text { al., 2018) }\end{array}$ \\
\hline \multirow{3}{*}{$\begin{array}{l}\text { Phenols and } \\
\text { PAHs }\end{array}$} & Sewage sludge & $\begin{array}{l}\text { Pyrolysis at } 500^{\circ} \mathrm{C} \text { for } 1 \\
\text { h/microwave-assisted } \\
\text { pyrolysis at } 980 \mathrm{~W} \text { for } 12 \mathrm{~min}\end{array}$ & Hydroquinone & $\begin{array}{l}1218.3 \mathrm{mg} \cdot \mathrm{g}^{-1} / 1202.1 \\
\mathrm{mg} \cdot \mathrm{g}^{-1}\end{array}$ & $\begin{array}{l}\text { (Dos Reis \& } \\
\text { Dias, 2016) }\end{array}$ \\
\hline & Malt spent rootlets & Pyrolysis at $800^{\circ} \mathrm{C}$ for $1 \mathrm{~h}$ & Phenanthrene & $23.5 \mathrm{mg} \cdot \mathrm{g}^{-1}$ & $\begin{array}{l}\text { (Valili et al., } \\
\text { 2013) }\end{array}$ \\
\hline & Orange peel & Pyrolysis at $150-700^{\circ} \mathrm{C}$ for $6 \mathrm{~h}$ & $\begin{array}{l}\text { Naphthalene and 1- } \\
\text { naphthol }\end{array}$ & $\begin{array}{l}80.8 \mathrm{mg} \cdot \mathrm{g}^{-1} \text { for } \\
\text { naphthalene and } 186.5 \\
\mathrm{mg} \cdot \mathrm{g}^{-1} \text { for } 1 \text {-naphthol }\end{array}$ & $\begin{array}{l}\text { (Chen \& } \\
\text { Chen, 2009) }\end{array}$ \\
\hline \multirow{4}{*}{ Pesticides } & $\begin{array}{l}\text { Maize straw and } \\
\text { pig manure }\end{array}$ & $\begin{array}{l}\text { Pyrolysis at } 300,500 \text {, and } \\
700^{\circ} \mathrm{C} \text { for } 4 \mathrm{~h}\end{array}$ & Thiacloprid & About $8.1 \mathrm{mg} \cdot \mathrm{g}^{-1}$ & $\begin{array}{l}\text { (Zhang et al., } \\
\text { 2018) }\end{array}$ \\
\hline & Almond shell & $\begin{array}{l}\text { Pyrolysis at } 650^{\circ} \mathrm{C} \text { for } 1 \mathrm{~h} \text { with } \\
\text { steam activation at } 800^{\circ} \mathrm{C}\end{array}$ & $\begin{array}{l}\text { Dibromochloroprop } \\
\text { ane }\end{array}$ & $102 \mathrm{mg} \cdot \mathrm{g}^{-1}$ & $\begin{array}{l}\text { (Klasson et } \\
\text { al., 2013) }\end{array}$ \\
\hline & Broiler litter & $\begin{array}{l}\text { Pyrolysis at } 350 \text { and } 700^{\circ} \mathrm{C} \\
\text { with and without steam } \\
\text { activation at } 800^{\circ} \mathrm{C}\end{array}$ & Deisopropylatrazine & $\begin{array}{l}\text { About } 83.3 \mathrm{mg} \cdot \mathrm{g}^{-1} \text { for } \\
\text { BL700 with steam } \\
\text { activation }\end{array}$ & $\begin{array}{l}\text { (Uchimiya et } \\
\text { al., 2010) }\end{array}$ \\
\hline & Maple, elm and oak & Pyrolysis at $450^{\circ} \mathrm{C}$ for $1 \mathrm{~h}$ & Atrazine and & $451-1158 \mathrm{mg} \cdot \mathrm{g}^{-1}$ for & (Zheng et al., \\
\hline
\end{tabular}




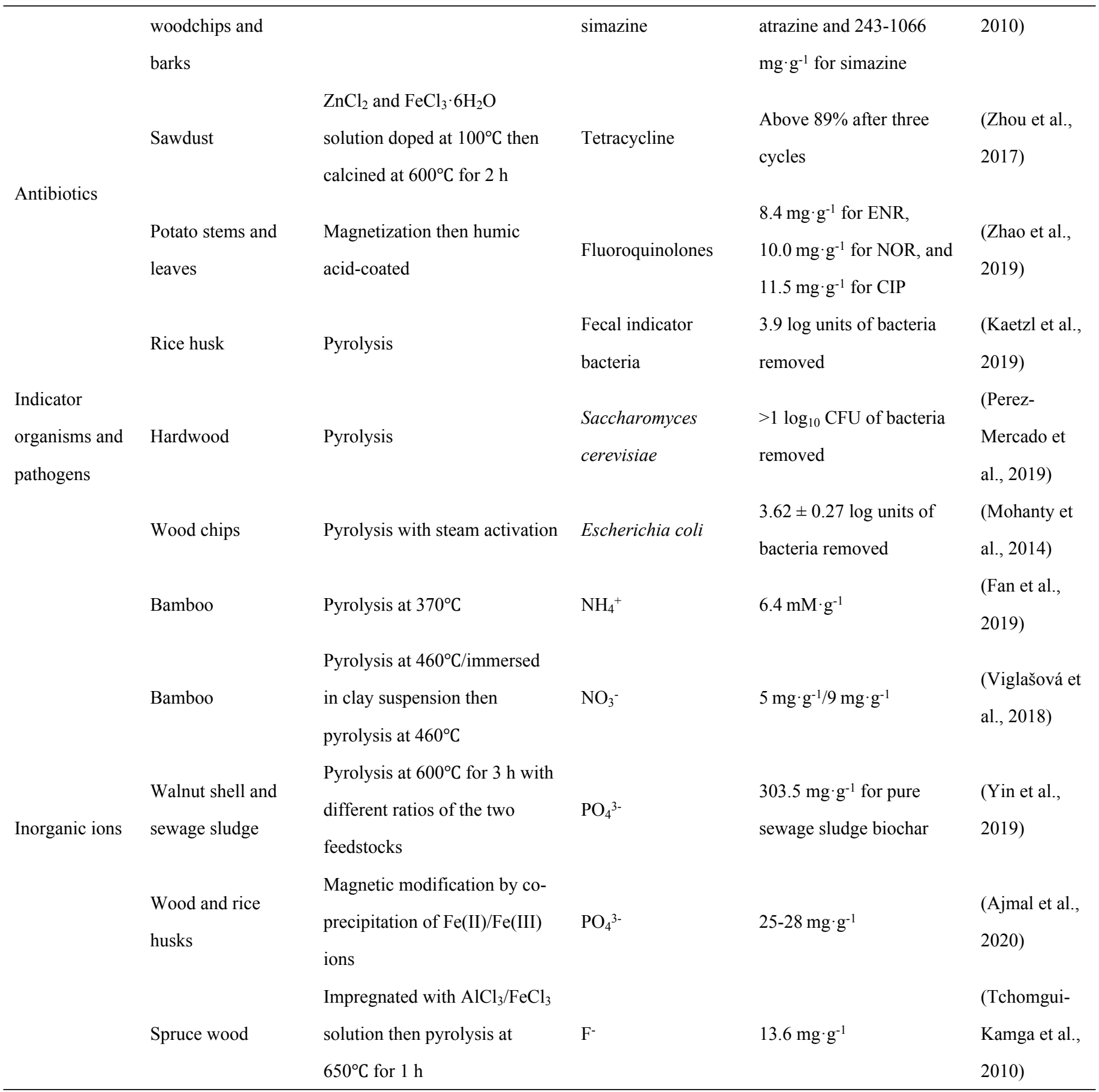


Figure 1

Sorption mechanisms of heavy metals and organic contaminants on biochar.

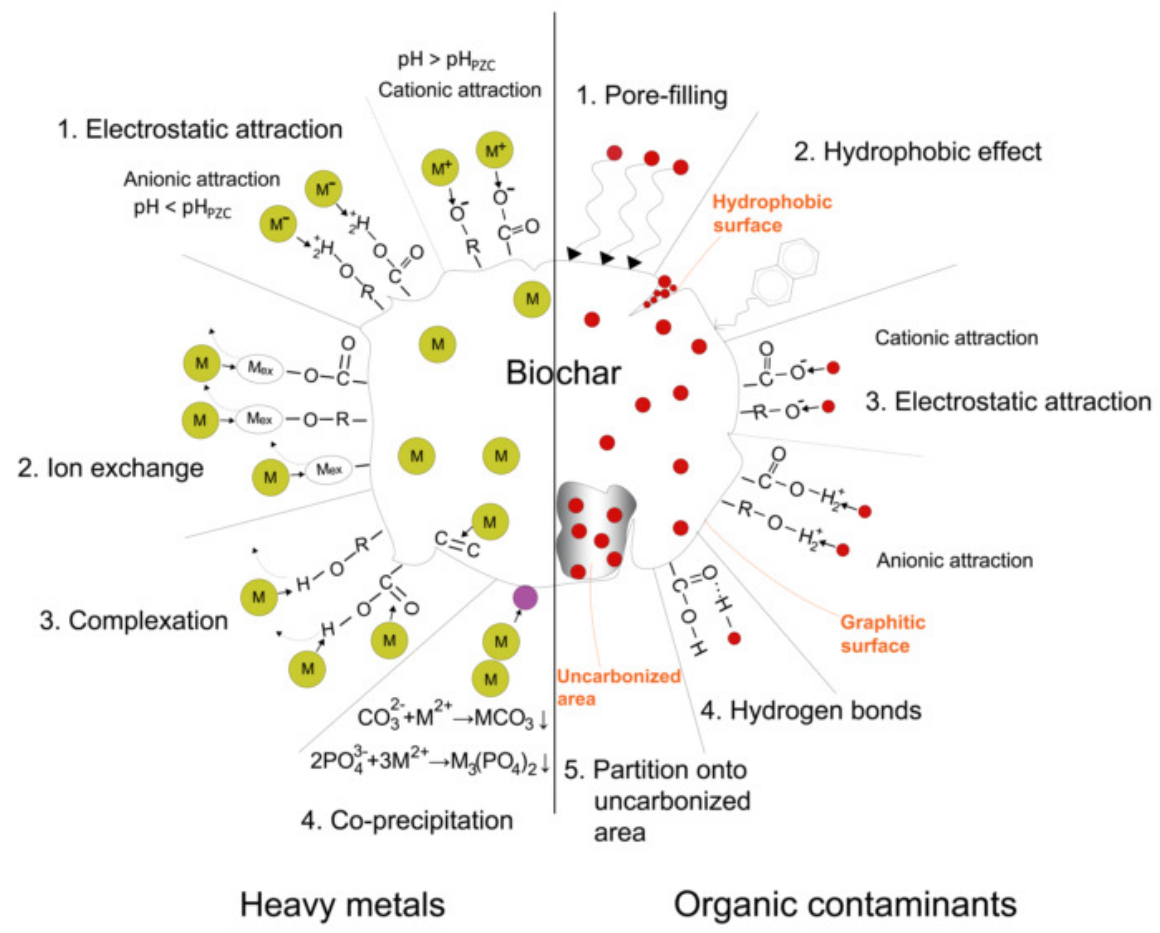

- Organic contaminants

M Metal ions

- Mineral components $\left(\mathrm{CO}_{3}^{2-}, \mathrm{PO}_{4}^{3-}\right)$

Mex Exchangeable metal ions 
Figure 2

Modification methods of biochar according to different emphases.

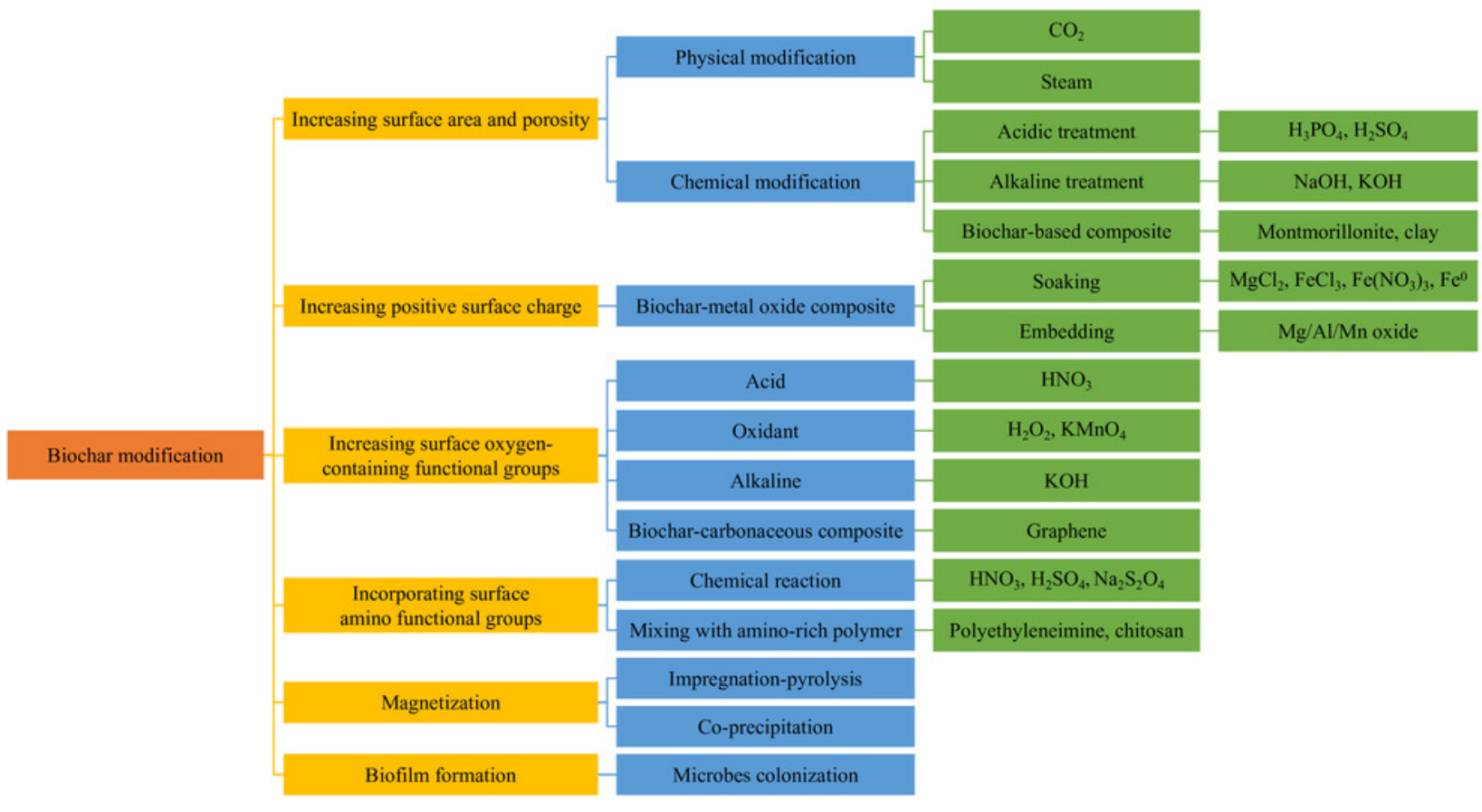


Figure 3

\section{Environmental concerns and future research directions of biochar application.}

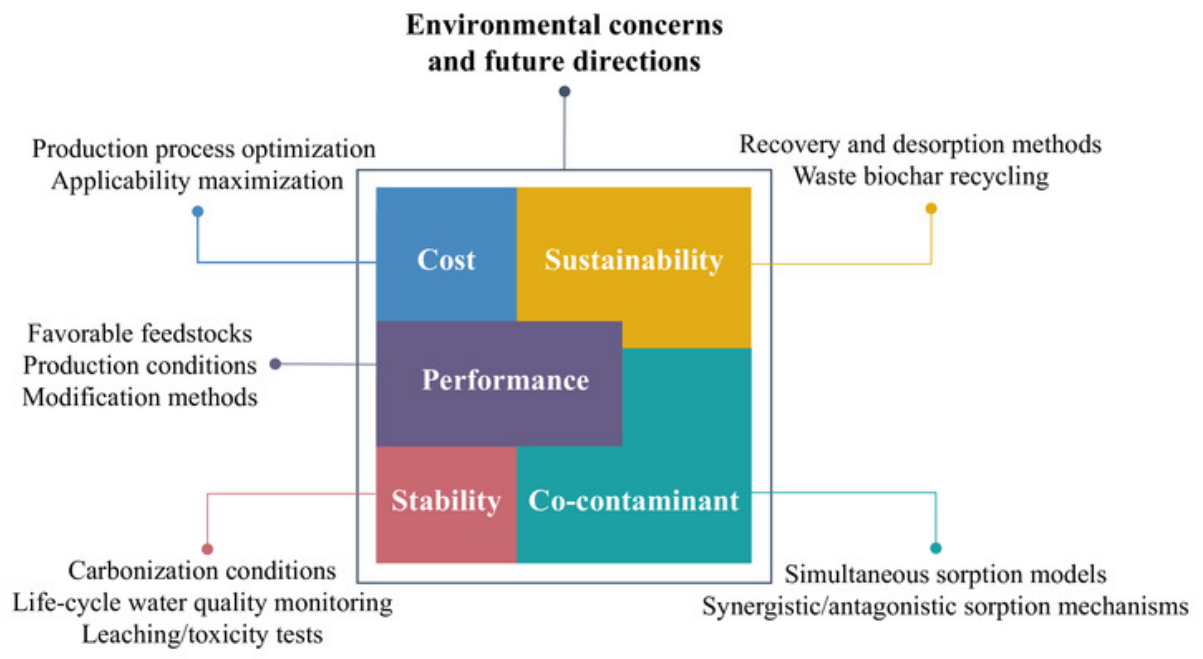

